\title{
The effect of local land-use changes on floristic diversity during the past 1000 years in southern Sweden
}

\author{
Daniel Fredh, 1,2 Florence Mazier, 1,3 Petra Bragée,' Per Lagerås, ${ }^{4}$ \\ Mats Rundgren,' Dan Hammarlund' and Anna Broström ${ }^{1,4}$
}

\begin{abstract}
The relationship between land-use and floristic diversity in the landscape, for the last millennia, is analysed from two small lakes in southern Sweden. Pollen analysis and the Local Vegetation Estimates (LOVE) model are used to quantify land-cover at local scales with 100-year time windows. Floristic richness is estimated using palynological richness, and we introduce LOVE-based evenness as a proxy for floristic evenness on a local scale based on the LOVE output. The results reveal a dynamic land-use pattern, with agricultural expansion during the 13th century, a partly abandoned landscape around AD 1400, re-establishment during the 15th-17th centuries and a transition from traditional to modern land-use during the 20th century. We suggest that the more heterogeneous landscape and the more dynamic land-use during the 13th-19th centuries were of substantial importance for achieving the high floristic diversity that characterises the traditional landscape. Pollen-based studies of this type are helpful in identifying landscape characteristics and landuse practices that are important for floristic diversity and may therefore guide the development of ecosystem management strategies aiming at mitigating the on-going loss of species seen in the landscape of southern Sweden and many other regions worldwide.
\end{abstract}

\section{Keywords}

ecosystem management, floristic diversity, land-use changes, late-Holocene, Local Vegetation Estimates model, pollen analysis, southern Sweden

Received 3I October 2013; revised manuscript accepted 25 July 2016

\section{Introduction}

Anthropogenic influence during recent decades has resulted in declining biodiversity, mainly because of profound and rapid land-use changes (Anton et al., 2010; Barnosky et al., 2011; MacDonald et al., 2008). To mitigate further loss of species, the development of a land-use system capable of combining production targets with preservation of biodiversity is needed (Emanuelsson, 2009; Harrison et al., 2010). However, to be able to implement such a land-use system, we need to increase our understanding of anthropogenic ecosystems at various temporal and spatial scales and increase our knowledge about the historical land-use and its impact on biodiversity (Dawson et al., 2011; Haslett et al., 2010; Jackson and Hobbs, 2009; Redman, 1999; Willis and Bhagwat, 2010; Willis et al., 2010).

In north-western Europe, species-rich areas related to traditional land-use, such as meadows and pastures, have become fragmented and remain only as islands in the modern production landscape (Cousins et al., 2007; Poschlod et al., 2005). In the province of Småland, southern Sweden, several land-use changes have occurred during the last 1000 years, which makes it a suitable area for studying the effect of changing land-use on biodiversity (Lagerås, 2007). A general agricultural expansion occurred during the Middle Ages, c. AD 900-1200, followed by the late Medieval agrarian crisis with population decline and land abandonment (Berglund et al., 2002; Lagerås, 2007; Myrdal, 2012). Farms were re-established during the 16th century and the maximum extent of agricultural land-use was reached in the late 19th century (Myrdal and Morell, 2011). Since then, the transition to modern land-use has resulted in the polarised landscape of today, characterised by dense tree plantations and large open fields, with very little semi-open vegetation and few permanent grasslands (Antonsson and Jansson, 2011). This reorganisation of the spatial land-use structure could potentially have had large impacts on biodiversity, for example, by reducing the connectivity between areas for seed dispersal (Cousins et al., 2007).

To study past land-use and biodiversity dynamics, palaeoecological tools may be used to provide information on past vegetation composition, which is not possible to extract from historical data and maps alone (Berglund et al., 2008; Cousins, 2011; Dahlström, 2008). Palaeoecological methodologies have advanced in recent years, especially with regard to the ability to quantify past vegetation change (Broström et al., 1998; Davis, 2000; Hellman et al., 2009; Sugita, 1994, 2007a, 2007b; Sugita et al., 1999). Based on pollen extracted from sediments, the Landscape Reconstruction Algorithm (LRA) uses two models, REVEALS

'Quaternary Sciences, Department of Geology, Lund University, Sweden 2 Museum of Archaeology, University of Stavanger, Norway ${ }^{3}$ GEODE, UMR 5602, Jean Jaurès University, France

${ }^{4}$ National Historical Museums, Sweden

\section{Corresponding author:}

Daniel Fredh, Museum of Archaeology, University of Stavanger, 4036 Stavanger, Norway.

Email: daniel.fredh@uis.no 
(Regional estimates of vegetation abundance from large sites) and LOVE (Local Vegetation Estimates), to quantify regional and local past vegetation abundance (Sugita, 2007a, 2007b).

Fredh et al. $(2012,2013)$ analysed the relationship between land-use and floristic diversity in the province of Småland between $600 \mathrm{BC}$ and $\mathrm{AD} 2008$, focussing on two different periods: one during the shift from agricultural expansion to regression recorded around AD 550 and one during the transition from traditional to modern land-use management at c. AD 1800-2008. These studies used a combination of the REVEALS model and palynological richness and introduced REVEALS-based evenness as a diversity measure of the regional vegetation abundances of the taxa reconstructed by the REVEALS model. The present study is carried out in the same area but focuses on vegetation at the local scale. The aims of this study are to

- Quantify local-scale land-use change during the last thousand years by applying 100-year time windows and the LOVE model to pollen data;

- Develop a method for reconstruction of past floristic diversity at the local scale, using a combination of palynological richness and an estimation of evenness based on the LOVE model;

- Compare and analyse the relationship between land-use and floristic diversity;

- Provide estimates of the degree of change in land-use required to promote floristic diversity.

\section{Study area}

We selected two lakes to reconstruct local vegetation changes (Åbodasjön, $57^{\circ} 05^{\prime} 08^{\prime \prime} \mathrm{N}, 14^{\circ} 28^{\prime} 57^{\prime \prime} \mathrm{E}, 50$ ha, and Lindhultsgöl, $\left.57^{\circ} 08^{\prime} 42^{\prime \prime} \mathrm{N}, 14^{\circ} 28^{\prime} 04^{\prime \prime} \mathrm{E}, 7 \mathrm{ha}\right)$ and a third one needed for the REVEALS modelling (Fiolen, 5704'56"N, 14³1'49"E, 160 ha). The two first lakes are situated in the parish of Slätthög, an elongated area covering $138 \mathrm{~km}^{2}$, in the central part of the province of Småland, southern Sweden (Figure 1). This area is part of the boreo-nemoral zone characterised by a mixture of coniferous and deciduous trees (Sjörs, 1963). Overall vegetation cover around the lakes is similar and dominated by managed coniferous woodland with patches of cultivated fields. However, in the vicinity of Åbodasjön, broadleaved trees and cultivated fields dominate, whereas managed coniferous woodlands and peat deposits constitute Lindhultsgöl's immediate surroundings. The mean annual temperature is $6.4^{\circ} \mathrm{C}$, the annual precipitation is $651 \mathrm{~mm}(1961-$ 1990 reference normal) and the bedrock is dominated by granite and gneiss, dominantly covered by sandy till and glaciofluvial deposits (Alexandersson et al., 1991; Fredén, 1994).

\section{Methods}

\section{Dating}

Samples were extracted from sediments, retrieved using Russian, gravity and/or piston corers (Jowsey, 1966; Renberg and Hansson, 2008), to establish chronologies using a combination of ${ }^{210} \mathrm{~Pb}$ records, radiocarbon dates and $\mathrm{Pb}$ pollution marker horizons (Appendix 1; Bragée et al., 2013; Fredh et al., 2013). Based on the activity of ${ }^{210} \mathrm{~Pb},{ }^{226} \mathrm{Ra}$ and ${ }^{137} \mathrm{Cs}$ obtained, the constant rate of supply (CRS) model was used to establish a chronology for the upper c. 30-45 cm of the sediment cores (Appleby, 2001). Beyond the reach of ${ }^{210} \mathrm{~Pb}$ dating, macroscopic plant remains and bulk samples were radiocarbon dated using accelerator mass spectrometry (AMS) and ${ }^{14} \mathrm{C}$ results were subsequently calibrated (Bronk Ramsey, 2009; Levin and Kromer, 2004; Levin et al., 2008; Reimer et al., 2009). Lead (Pb) concentration data and/or lead isotope ratios $\left({ }^{206 \mathrm{~Pb}} / 207 \mathrm{~Pb}\right)$, obtained by XRF analysis (Boyle, 2000) and Quadrapole ICP-MS, were also included in the age models based on the regionally coherent pattern of airborne pollution $\mathrm{Pb}$ deposition across Sweden during recent millennia (Brännvall et al., 2001; Renberg et al., 2001). Using the combined data obtained, Bayesian analysis in the OxCal program (v. 4.1) was used to create age-depth models (Bronk Ramsey, 2008, 2009).

For Fiolen, the chronological data provided by the different methods were partly inconsistent, making it necessary to select the data points to be used in the final age-depth model (Fredh et al., 2013). The preferred age-depth model was based on six terrestrial plant macrofossil samples (three pre-treated), a CRS model (based on nine ${ }^{210} \mathrm{~Pb}$ samples) and four lead pollution markers. Eight small plant macrofossil samples (not pre-treated) were rejected as well as $17{ }^{210} \mathrm{~Pb}$-measured samples below $15 \mathrm{~cm}$ were considered unreliable. Clearly, establishing a chronology for the Lake Fiolen sediment sequence was not straightforward, and Fredh et al. (2013) considered several options before concluding that the above detailed age-depth model is the most probable one. Assuming this age model is correct, the maximum uncertainty $(2 \sigma)$ provided by $\mathrm{OxCal}$ is \pm 170 years.

For Åbodasjön and Lindhultsgöl, the age-depth models are based on fewer data points, but the chronological data are more consistent (Bragée et al., 2013). The radiocarbon dates obtained on terrestrial plant macrofossils fall along the trajectories defined by extrapolated ${ }^{210} \mathrm{~Pb}$ data and $\mathrm{Pb}$ pollution marker horizons. In contrast, all bulk sediment ${ }^{14} \mathrm{C}$ dates display substantially higher calibrated ages as compared with these trends, and were thus not used for age modelling. The age-depth model for Åbodasjön was based on three terrestrial plant macrofossil ${ }^{14} \mathrm{C}$ dates, a CRS model (based on $25^{210} \mathrm{~Pb}$ samples) and four pollution marker horizons. The age-depth model for Lindhultsgöl was based on two terrestrial macrofossil ${ }^{14} \mathrm{C}$ dates, a CRS model (based on $20{ }^{210} \mathrm{~Pb}$ samples) and five pollution marker horizons (Bragée et al., 2013). Four radiocarbon dates obtained on bulk sediment samples were rejected for Åbodasjön, and three bulk sediment dates were not used for the Lindhultsgöl age-depth model. The maximum uncertainty $(2 \sigma)$ provided by $\mathrm{OxCal}$ is $\mathrm{c}$. \pm 80 years for Åbodasjön and c. \pm 100 years for Lindhultsgöl. An additional uncertainty, but of a different character, applies to the Lindhultsgöl record where relatively large $(4$ and $10 \mathrm{~cm})$ depth intervals had to be used to obtain sufficient macroscopic plant remains for dating.

\section{Pollen and charcoal analysis}

Material for pollen and charcoal analysis was subsampled from the sediment cores at 0.5 - to $10-\mathrm{cm}$ intervals. The samples were prepared using standard methods for pollen analysis and mounted on slides for further counting of pollen and microscopic charcoal (10-200 $\mu \mathrm{m})$ using a light microscope (Berglund and RalskaJasiewiczowa, 1986). Pollen grains were identified to species level, where possible, facilitated by keys (Beug, 1961, 2004; Moore et al., 1991; Punt, 2003 [1976]) and the reference collection at the Department of Geology, Lund University. For detailed examination, phase contrast microscopy under oil immersion at $1000 \times$ magnification was used, for example, for separation between different genera of Cerealia based on the structure of the pollen wall (Beug, 2004).

For the purpose of subsequent modelling and rarefaction analysis, several pollen levels were pooled together. Considering the uncertainty of the chronologies, we chose to use 100-year time windows for all sites, that is, 10 bins over the last 1000 years (Appendix 2). In total, 100 levels were pooled together for Fiolen (1687-6469 pollen grains/time window), 112 levels for Åbodasjön (2050-11,769 pollen grains/time window) and 74 levels for Lindhultsgöl (2147- 7087 pollen grains/time window). Using this approach, we were able to quantify the magnitude of the majority 


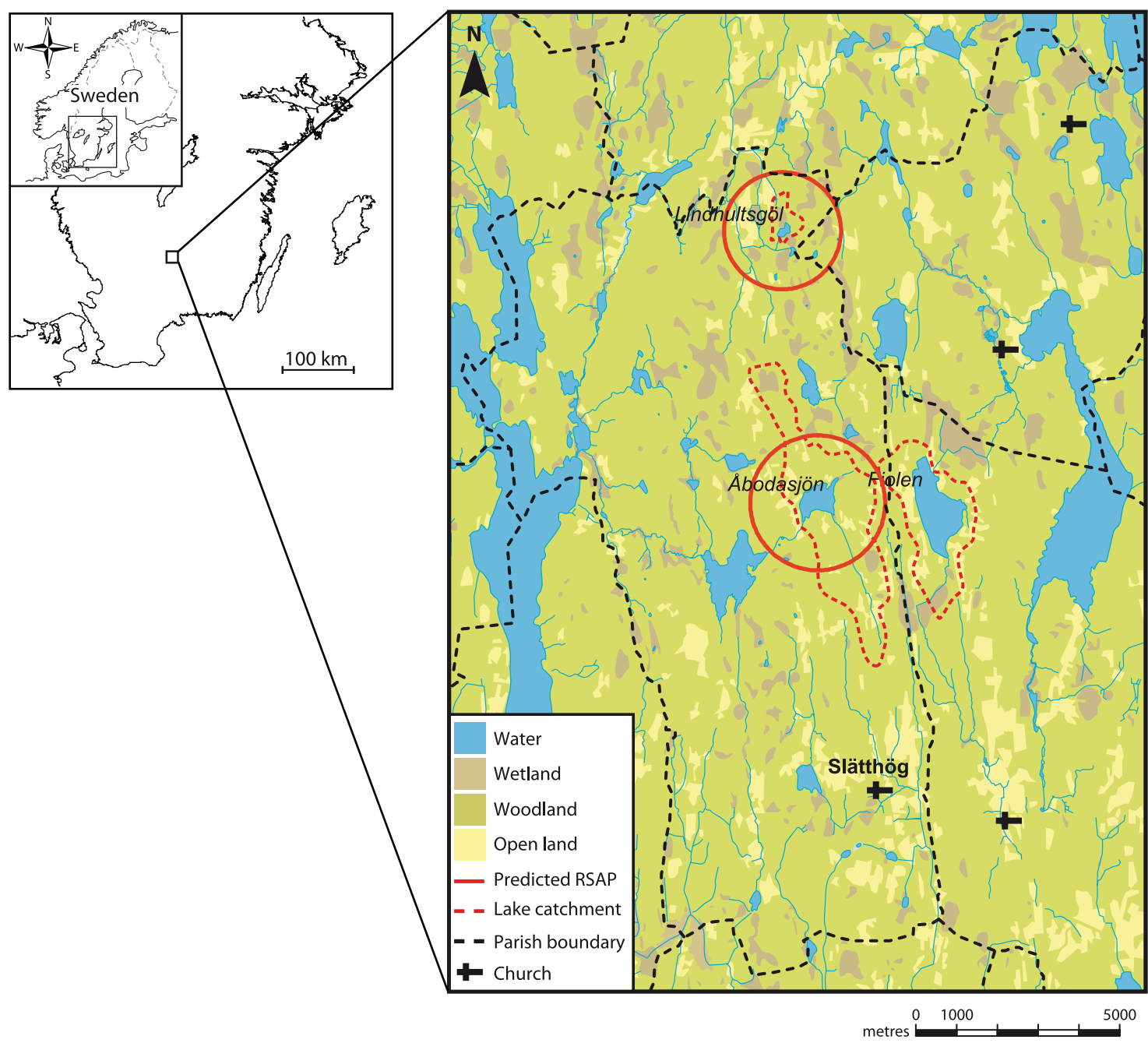

Figure I. Locations of Lakes Fiolen, Åbodasjön and Lindhultsgöl in southern Sweden. Red circles show the predicted relevant source area of pollen (predicted RSAP) around Åbodasjön and Lindhultsgöl, 1740 and 1440 m, respectively (Mazier et al., 20I5). Parish boundaries (black dashed lines), catchments for the respective lakes (red dashed lines) and the modern land-cover are also shown.

of the land-use changes during the last 1000 years inferred from pollen data, although we cannot capture the exact timing of these events within each time window.

Charcoal fragments $(10-200 \mu \mathrm{m})$ were counted simultaneously with pollen grains, and sample data were in the same way pooled together in 100-year time windows. Tablets containing a known number of Lycopodium clavatum spores (Stockmarr, 1971) were added to $1 \mathrm{~cm}^{3}$ sediment samples for estimation of charcoal concentrations based on the total charcoal abundance for each time window. Subsequently, charcoal accumulation rates (CHAR) were calculated for each time window using the Tilia software, v. 1.7.16 (Grimm, 1992). The CHAR estimates were used to infer regional changes in fire activity, which may reflect both human and natural processes (Conedera et al., 2009).

\section{Modelling of vegetation cover}

To be able to separate between regional and local pollen sources, Sugita (1994) defined the term relevant source area of pollen (RSAP), which is defined as the distance beyond which correlations between pollen loading and vegetation abundance do not continue to improve. The background pollen loading that originates from beyond this distance can be considered as a constant for similar-sized lakes within a region at a specific time. Within the RSAP, the pollen loading may vary between sites depending on local vegetation composition.

Based on this distinction, Sugita (2007a, 2007b) developed the LRA approach which comprises two steps. First, the REVEALS model uses pollen counts from large lakes $\left(1-5 \mathrm{~km}^{2}\right)$ to estimate regional vegetation composition $\left(10^{4}-10^{5} \mathrm{~km}^{2}\right)$. Second, the LOVE model uses pollen counts from small lakes $\left(0.01-1 \mathrm{~km}^{2}\right)$ to reconstruct local vegetation within the RSAP $\left(2-20 \mathrm{~km}^{2}\right)$ by estimating the background pollen loading based on the regional plant abundances estimates obtained with REVEALS. The size of the RSAP depends mainly on lake size and spatial patterns and patchiness of plant communities in the region (Broström et al., 2005; Bunting et al., 2004; Sugita, 1994; Sugita et al., 2010).

In this study, we used the LOVE model to quantify vegetation proportions within the RSAP at Åbodasjön and Lindhultsgöl, separately (Sugita, 2007a, 2007b; Sugita et al., 2010). In the first step, we used the REVEALS model to estimate the regional vegetation based on two sites, as previous studies have suggested that pollen records from multiple sites increase the reliability of the REVEALS estimates (Hellman et al., 2008; Mazier et al., 2012; Sugita, 2007a; Sugita et al., 2010). The REVEALS model was applied to pollen counts from Fiolen and Åbodasjön, and subsequently, the LOVE model was applied to pollen counts from Lindhultsgöl. Similarly, the REVEALS model was applied to pollen counts from Fiolen and Lindhultsgöl, and subsequently, the LOVE model was applied to pollen counts from Åbodasjön.

The LOVE model includes an estimation of the RSAP at each site using an inverse modelling approach; this site-specific area is defined as the smallest radius at which all modelled taxa reach positive values between 0.0 and 1.0 (Sugita, 2007b; Sugita et al., 2010). In theory, the larger the number of sites studied, the more robust the 
estimate of the 'LRA-based RSAP'. However, because we use pollen records from only one site for vegetation reconstruction around Åbodasjön and Lindhultsgöl, it is difficult to reliably estimate the RSAP. Instead a forward-modelling approach (Sugita, 1994; Sugita et al., 1999), based on modern landscapes, was applied to estimate the RSAP. These predicted RSAPs for Åbodasjön and Lindhultsgöl are within radii of 1740 and $1440 \mathrm{~m}$ from their lake centres, respectively (Mazier et al., 2015; Figure 1). These RSAPs are hereafter considered as the spatial units of vegetation reconstruction around the sites and are assumed to be constant through time for our reconstructions.

The LOVE model provides vegetation estimates expressed as distance-weighted plant abundance (DWPA) within the RSAP, which means that the LOVE model takes into consideration that plants closer to the sample point contribute more grains to the pollen assemblage than plants further away (Sugita, 2007b). Here, we assume that the DWPA for each taxon represents its spatial cover within the RSAP.

The REVEALS and LOVE models require raw pollen counts, various parameter inputs and assumptions. We used pollen productivity estimates (PPEs) and their standard errors (SEs) for 26 taxa as defined in southern Sweden and Denmark (Table 1) and fall speeds of pollen from the literature (Broström et al., 2004, 2008; Eisenhut, 1961; Mazier et al., 2012; Nielsen, 2004; Sugita et al., 1999). The LRA assumes pollen transport above the canopy, uniform wind in all directions and constant PPE through time (Prentice, 1985, 1988; Sugita, 1993, 1994, 2007a, 2007b). The lake radius was set to $714 \mathrm{~m}$ for Fiolen, $400 \mathrm{~m}$ for Åbodasjön and $150 \mathrm{~m}$ for Lindhultsgöl, and the Ring Source model of pollen dispersal and deposition for lakes was used (Sugita et al., 1999). The wind speed was set to $3 \mathrm{~m} \mathrm{~s}^{-1}$ and $Z_{\max }$, maximum spatial extent of the regional vegetation, to $50 \mathrm{~km}$ as in Mazier et al. (2012). SEs for the estimates of regional and local vegetation abundance, respectively, were calculated in the REVEALS (v. 4.2.2) and LOVE (v. 3.2.0) programs using a variant of the delta method (Stuart and Ord, 1994; Sugita, 2007b).

\section{Estimation of floristic diversity}

Palynological richness. In this study, we used palynological richness, the number of different pollen and spore taxa identified in each sample, as a proxy for floristic diversity (Birks and Line, 1992; Birks et al., 2016). Due to differences in total pollen counts between time windows, palynological richness was recalculated using rarefaction analysis (Birks and Line, 1992). This measure is expressed as the expected number of pollen taxa for a constant pollen sum, the minimum pollen sum across all sites $(N=2075)$. The calculations were based on all terrestrial taxa, in total 124 and 79 for Åbodasjön and Lindhultsgöl, respectively. The palynological richness is based on raw pollen data and the pollen source area is therefore not defined. Consequently, this measure probably includes both a regional and a local component. Although this measure only represents a small fraction of all species in the surrounding vegetation, palynological richness has shown to be useful for estimation of floristic richness (Birks et al., 2016; Meltsov et al., 2011, 2012; Odgaard, 2007; Van der Knaap, 2009).

LOVE-based evenness. Fredh et al. $(2012,2013)$ used REVEALSbased evenness, which is the relative abundance of taxa reconstructed by the REVEALS model, as a proxy for floristic evenness at the regional scale. In this paper, we introduce LOVEbased evenness as a proxy for floristic evenness at the local scale. Based on the proportional abundances estimated by the LOVE model, we calculated the Shannon index, which combines the number of taxa and the relative abundance of taxa to estimate floristic diversity (Magurran, 2004; Odgaard, 2007; Van Dyke,
Table I. Fall speed of pollen, relative pollen productivity estimates (PPEs) and associated standard errors (SEs) for 26 taxa obtained for southern Sweden (Broström et al., 2004; Hellman et al., 2008; Mazier et al., 2012; Sugita et al., 1999) and Denmark (numbers in bold; Nielsen, 2004) used in the REVEALS and LOVE model runs.

\begin{tabular}{llll}
\hline Pollen taxa & Fall speed $\left(\mathrm{m} \mathrm{s}^{-1}\right)$ & PPE & SE \\
\hline Acer & 0.056 & 1.267 & 0.452 \\
Alnus & 0.021 & 4.200 & 0.140 \\
Betula & 0.024 & 8.867 & 0.134 \\
Calluna vulgaris & 0.038 & 1.102 & $\mathbf{0 . 0 5 4}$ \\
Carpinus & 0.042 & 2.533 & 0.070 \\
Cerealia-t & 0.060 & $\mathbf{0 . 7 4 7}$ & $\mathbf{0 . 0 3 9}$ \\
Comp. SF. Cichorioideae & 0.051 & 0.244 & 0.065 \\
Corylus & 0.025 & 1.400 & 0.042 \\
Cyperaceae & 0.035 & 1.002 & 0.164 \\
Fagus & 0.057 & 6.667 & 0.173 \\
Filipendula & 0.006 & 2.480 & 0.821 \\
Fraxinus & 0.022 & 0.667 & 0.027 \\
Juniperus & 0.016 & 2.067 & 0.036 \\
Picea & 0.056 & 1.757 & 0.000 \\
Pinus & 0.031 & 5.663 & 0.000 \\
Plantago lanceolata & 0.029 & 0.897 & 0.235 \\
Poaceae & 0.035 & 1.000 & 0.000 \\
Potentilla-t & 0.018 & 2.475 & 0.377 \\
Quercus & 0.035 & 7.533 & 0.083 \\
Ranunculus acris-t & 0.014 & 3.848 & 0.718 \\
Rubiaceae & 0.019 & 3.946 & 0.589 \\
Rumex acetosa-t & 0.018 & 1.559 & $\mathbf{0 . 0 8 9}$ \\
Salix & 0.022 & 1.267 & 0.313 \\
Secale-t & 0.060 & 3.017 & 0.052 \\
Tilia & 0.032 & 0.800 & 0.029 \\
Ulmus & 0.032 & 1.267 & 0.050 \\
\hline & & & \\
\hline
\end{tabular}

REVEALS: Regional estimates of vegetation abundance from large sites; LOVE: Local Vegetation Estimates.

2008). Subsequently, we calculated floristic evenness using the ratio between Shannon index and maximum evenness for each time window, when all taxa are equally frequent, also known as the Pielou's evenness index (Magurran, 2004; Odgaard, 2007; Pielou, 1966). Pielou's evenness index (and in this case LOVEbased evenness) varies between 0 and 1 , with an index of 1 when all taxa cover equal proportions of the reconstructed area. Lower values are attained when a few taxa cover large proportions and other taxa cover small proportion within an area. We estimated LOVE-based evenness for all 26 taxa used in the LOVE model within the RSAP, but also for trees and herbs separately. We assume that the LOVE output represents actual vegetation cover and not DWPA. Because this is not always the case, our values of LOVE-based evenness should be considered as tentative.

\section{Results}

\section{Vegetation cover}

Estimated vegetation cover within the predicted RSAPs of Åbodasjön and Lindhultsgöl (1740 and $1440 \mathrm{~m}$, respectively) using the LOVE model for 26 taxa is shown in Figures 2 and 3. At both Åbodasjön and Lindhultsgöl, Picea, Corylus, Juniperus, Poaceae, Cerealia type (Hordeum + Avena + Triticum), Carpinus, Fraxinus, Salix, Tilia, Ulmus, Rumex acetosa type, Compositae SF. Cichorioideae, Cyperaceae, Acer, Filipendula, Plantago lanceolata and Secale type were underestimated in pollen percentages compared with LOVE-based vegetation cover, while Pinus, Betula, Fagus and Quercus were overestimated in pollen percentages compared with LOVE-based vegetation cover. Calluna vulgaris 

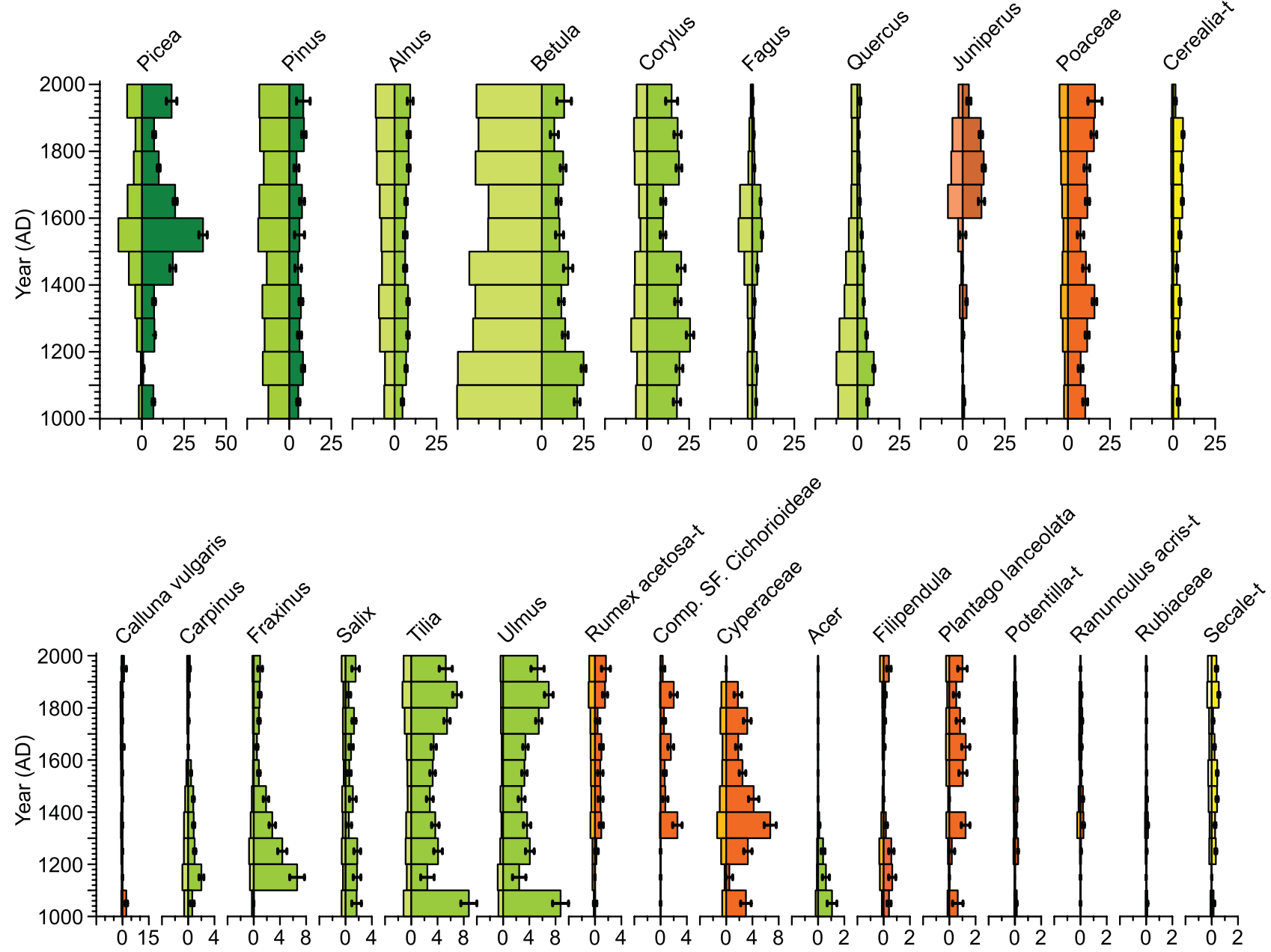

Figure 2. Lake Åbodasjön. Pollen percentage diagram (left side) and estimated local vegetation proportions within RSAP (right side) at I00year time windows for 26 taxa, based on pollen analysis and the LOVE model. Note the different scales for the upper and lower parts of the figure, and within the lower figure.

was underestimated in pollen percentages compared with LOVEbased vegetation cover at Lindhultsgöl.

At Åbodasjön, the dominant taxa were Picea, Betula, Corylus and Poaceae, and at Lindhultsgöl they were Picea, Pinus, Betula, Poaceae and Calluna vulgaris. The major differences in vegetation cover between the two lakes are that Calluna vulgaris had 3-18\% higher cover at Lindhultsgöl than at Åbodasjön, Pinus had $2-15 \%$ higher cover at Lindhultsgöl than at Åbodasjön, and Corylus had up to $15 \%$ higher cover at Åbodasjön than at Lindhultsgöl.

Some major vegetation changes during the past 1000 years were similarly recorded at Åbodasjön and Lindhultsgöl. Carpinus, Quercus and Fraxinus decreased from $18 \%$ to $2 \%$ at Åbodasjön during the 13 th -17 th centuries and from $17 \%$ to $2 \%$ cover at Lindhultsgöl during the 12th-15th centuries and remained at lower levels throughout the sequences. In general, Picea showed two periods with higher cover at both lakes. At Åbodasjön, this occurred during the 15 th -17 th centuries and during the 20 th century. At Lindhultsgöl, this occurred during the 14th-18th centuries and during the 20th century. During the first of these periods, Fagus followed largely the same development at both lakes.

The degree of openness was estimated for each time window by amalgamating the cover for all 12 herb taxa (Figures 4 and 5). Openness varied between $9 \%$ and 32\% at Åbodasjön and between $17 \%$ and $44 \%$ at Lindhultsgöl. The higher degree of openness at Lindhultsgöl is mainly due to the larger cover of Calluna vulgaris (5- $18 \%$ at Lindhultsgöl compared with $0-2 \%$ at Åbodasjön). Maximum openness was recorded during the 14th century and during the 17th-20th centuries at Lake Åbodasjön and during the 18th-20th centuries at Lake Lindhultsgöl.

\section{Palynological richness and LOVE-based evenness}

During the studied period, palynological richness varied between 37 and 49 at Åbodasjön and between 30 and 42 at Lindhultsgöl (Figures 4 and 5). The highest values were recorded during the 14th-19th centuries at Åbodasjön and during the 18th-20th centuries at Lindhultsgöl. The total LOVE-based evenness varied between 0.72 and 0.81 at Åbodasjön and between 0.73 and 0.83 at Lindhultsgöl (Figures 4 and 5 ). Both total and tree evenness were relatively high at Lindhultsgöl throughout the studied period, showing that tree evenness dominates the total evenness calculation. Total evenness and tree evenness were generally high at Åbodasjön with slightly lower values during the 16 th century. Evenness for herbs was rather variable at both lakes.

\section{Charcoal}

The CHAR in the analysed sediment records from Åbodasjön and Lindhultsgöl vary between 600 and 7200 and between 300 and 4000 fragments $\mathrm{cm}^{-2}$ year-1, respectively (Figures 4 and 5). At both lakes, a rise in CHAR was recorded during the 13th century, followed by a minor decline at Lindhultsgöl during the 15th century. Thereafter, there was an increase from the 18th century at Åbodasjön and from the 17th century at Lindhultsgöl. The highest CHAR values were recorded during the 19th century, followed by lower values during the 20th century.

\section{Discussion}

Based on the vegetation changes inferred from the LOVE models, we identified four and five land-use periods for Lindhultsgöl and 

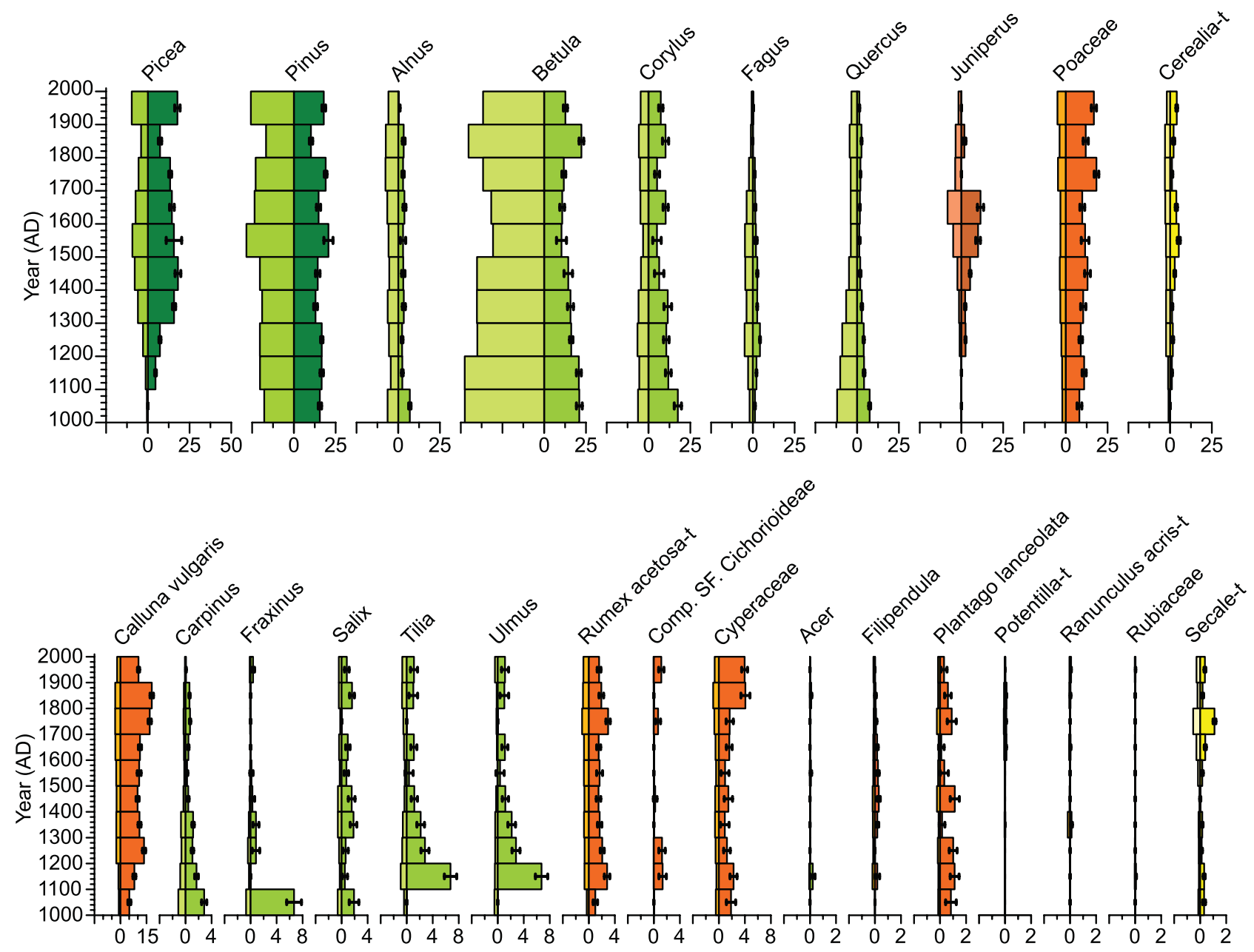

Figure 3. Lake Lindhultsgöl. Pollen percentage diagram (left side) and estimated local vegetation proportions within RSAP (right side) at I00year time windows for 26 taxa, based on pollen analysis and the LOVE model. Note the different scales for the upper and lower parts of the figure, and within the lower figure.

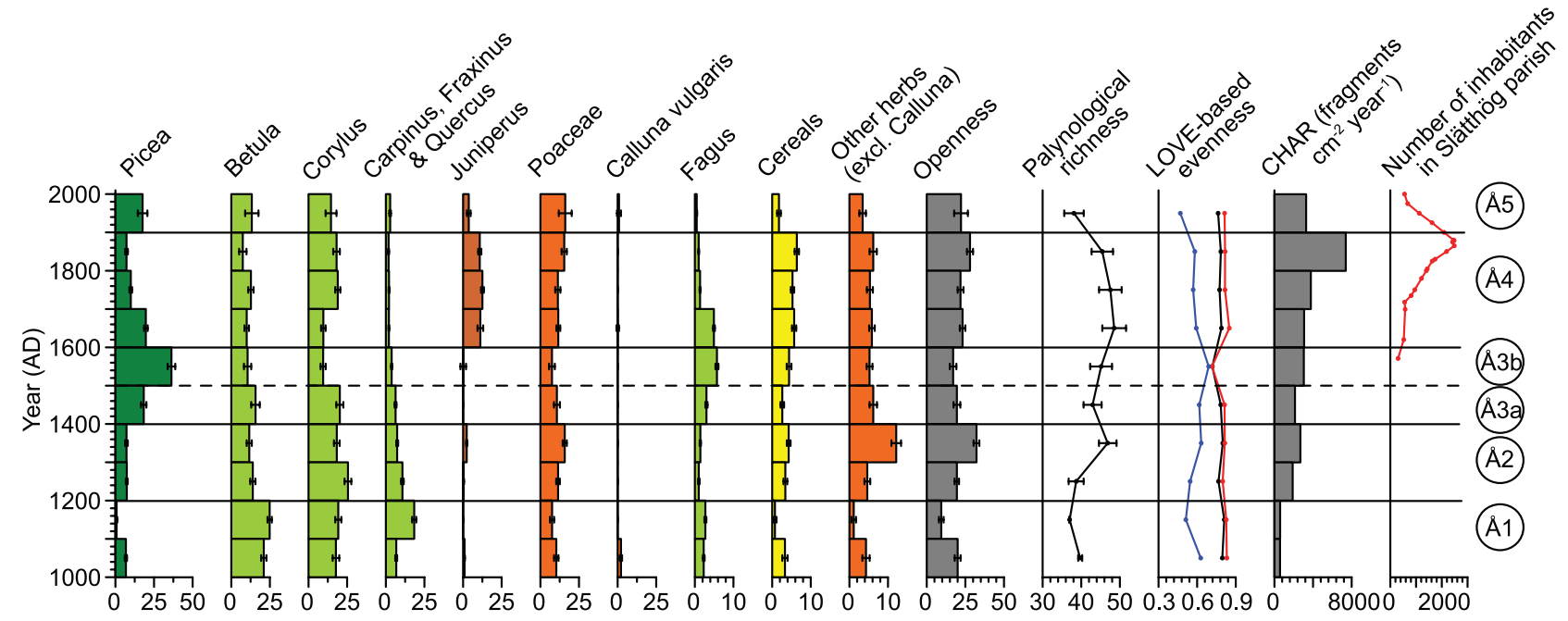

Figure 4. Lake Åbodasjön. Estimates of local vegetation cover for selected taxa/taxa groups, openness, palynological richness, LOVE-based evenness, charcoal accumulation rate (CHAR) and population in Slätthög parish. Cereals include both Cerealia type and Secale type. Openness includes all herb taxa and Calluna vulgaris. LOVE-based evenness was calculated for all 26 reconstructed taxa (black line), trees (red line) and herbs (blue line) taxa. We divided the sequence into five major land-use periods ( $\AA \mathrm{I}-\AA \AA 5$ ).

Åbodasjön, respectively (Figures 4 and 5). Land-use periods ( $\AA 1-$ $\AA 5$ and L1-L4) were defined visually based on changes in vegetation cover, mainly cereals (Cerealia type + Secale type) to estimate the extent of cultivated fields, and Poaceae and 'other herbs' to infer the extent of meadows, pastures and wetlands. Other herbs include Compositae SF. Cichorioideae, Cyperaceae, Filipendula, Plantago lanceolata, Potentilla type, Ranunculus acris type, Rubiaceae and Rumex acetosa type. To infer changes in agricultural land-use, we also used the cover of taxa that are favoured by open land, such as Juniperus and Corylus, as well as changes in 


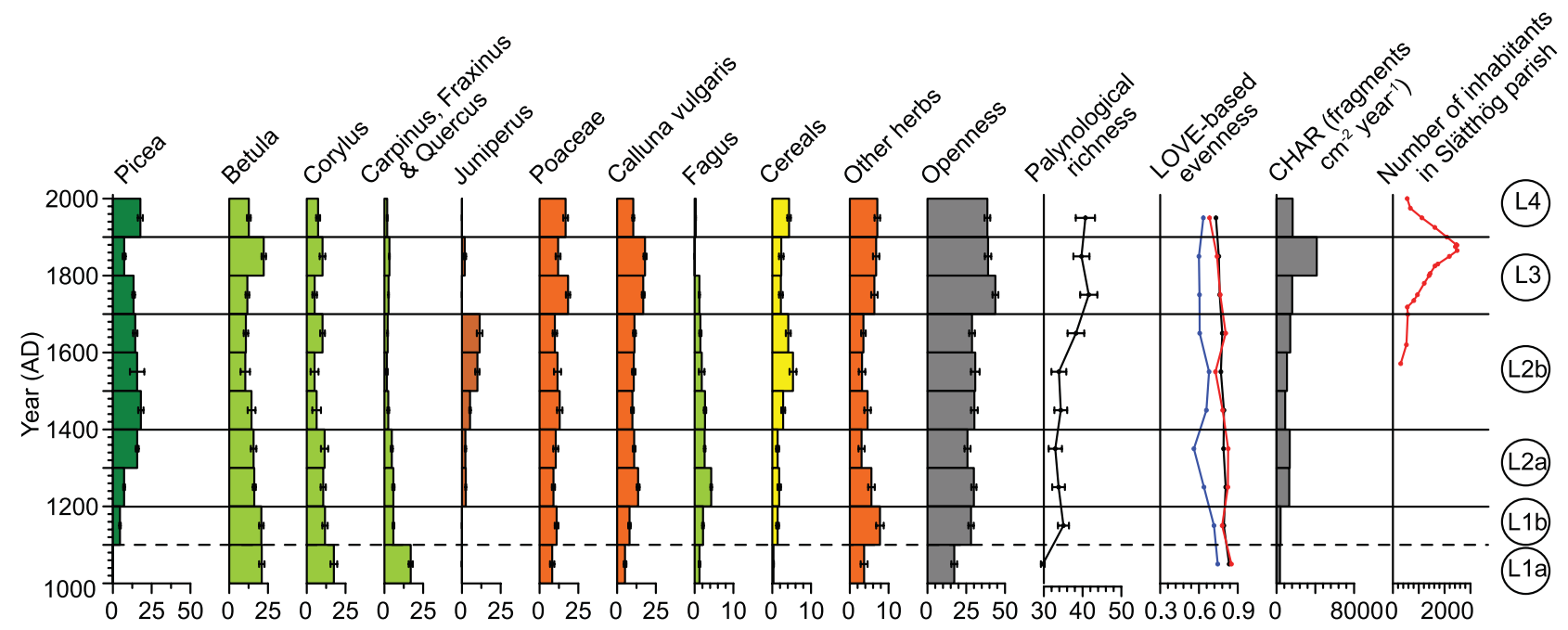

Figure 5. Lake Lindhultsgöl. Estimates of local vegetation cover for selected taxa/taxa groups, openness, palynological richness, LOVE-based evenness, charcoal accumulation rate (CHAR) and population in Slätthög parish. Cereals include both Cerealia type and Secale type. Openness includes all herb taxa and Calluna vulgaris. LOVE-based evenness was calculated for all 26 reconstructed taxa (black line), trees (red line) and herbs (blue line) taxa. We divided the sequence into four major land-use periods (LI-L4).

woodland taxa considered as late successional trees, such as Carpinus, Fraxinus and Quercus.

\section{Medieval expansion}

The continuous presence of agricultural land-use indicators, such as cereals, grasses and other herbs, suggests that agricultural land, including cultivated fields and grasslands, was present within the RSAP of both lakes throughout the last 1000 years. Moreover, at both sites, there are indications of agricultural expansion during the 13th century ( $\AA 2$ and L2). At Åbodasjön, this is shown by an increase in cereals, Poaceae, Juniperus, other herbs and CHAR (Figure 4), whereas at Lindhultsgöl this is indicated by an increase in Calluna vulgaris, Juniperus and CHAR (Figure 5). These differences indicate that crop cultivation was more extensive at Åbodasjön compared with Lindhultsgöl at this time and that the land management may have differed between the two areas. However, the expansion appears to have started slightly earlier at Lindhultsgöl, with an increase in cereals and other herbs during the 12th century (L1b), indicating that the agricultural expansion phase was more prolonged at this site. At Åbodasjön, several herb taxa related to meadows and pastures increased during this period, such as Apiaceae, Compositae SF. Cichorioideae, Ranunculus acris type, Trifolium type and Plantago lanceolata, while Filipendula declined (Appendix 2). Also taxa related to ruderal communities, such as Anthemis type and Plantago major, and a taxon related to forest, such as Anemone nemorosa, increased during this period (Appendix 2). The higher cover of Calluna vulgaris at Lindhultsgöl can partly be explained by the fact that more peat deposits are situated close to this lake, where some Calluna vulgaris grow today (Mazier et al., 2015). However, Calluna vulgaris may also grow in woodland understorey and may occur in grazed heathland (Cui et al., 2014). At both lakes, the increased cover of agricultural land occurred partly at the expense of Carpinus, Fraxinus and Quercus, which suggests that the areas where these taxa grew were suitable for agricultural land-use. Possibly this agricultural expansion represents the transition from shifting cultivation to farming based on permanent fields or simply that agriculture became more widespread. Shifting cultivation involved long-term fallow of 20-30 years to restore soil nutrients between cultivation periods (Emanuelsson, 2009). Permanent cultivation may also have had fallow periods, but they were much shorter, and productivity depended most of all on manuring. Permanent fields were situated close to settlements and were surrounded by meadows and pastures further away (Myrdal and Morell, 2011).

The agricultural expansion during the 13th century $(\AA 2)$ at Åbodasjön and 12th century at Lindhultsgöl (L1b) was accompanied by increased palynological richness, which suggests that floristic richness was favoured by more widespread traditional agriculture. Possibly, the agricultural system with permanent fields contributed to the increased floristic richness (Emanuelsson, 2009). This new agricultural system resulted in a higher gradient in land-use intensity, which was most intense around the farms/ villages with cultivated fields and meadows, and decreased towards the more distant pastures and woodlands (Emanuelsson, 2009; Myrdal and Morell, 2011). This heterogeneous landscape resulted in more widespread ecotones, that is, transitional areas between land-use types. Agricultural expansions during the Middle Ages comparable to the ones observed here have been recorded in numerous local pollen diagrams from the uplands of southern Sweden at c. AD 900-1200 (Berglund et al., 2002; Lagerås, 2007; Lagerås et al., 2016; Lindbladh, 1999).

\section{Late-medieval decline}

At Åbodasjön, a succession from open land to increased woodland cover was recorded in two phases (Figure 4). The first phase during the 15 th century ( $\AA 3 \mathrm{a}$ ) was characterised by increasing cover of Picea and Fagus, while Juniperus, Poaceae and other herbs declined, which suggests that parts of the agricultural landscape were abandoned and overgrown by trees. In the second phase during the 16th century ( $\AA 3 \mathrm{~b}$ ), Picea and Fagus expanded further at the expense of Betula and Corylus and reached their maxima. A slightly increased cover of Betula and Corylus during the first succession phase ( $\AA 3 \mathrm{a})$ possibly suggests these taxa occurred sparsely in the pastures and could expand rapidly when these areas were abandoned, but were later outcompeted when Picea and Fagus expanded into these areas.

Openness decreased from $32 \%$ to $17 \%$ during the entire period ( $\AA 3$ ), which indicates that almost half of the previously open land was abandoned. However, the cover of cereals was comparable to the previous period $(\AA 2)$, which suggests that crop cultivation was maintained and pastures were overgrown. This change in openness suggests that the extent of meadows and pastures declined by about $40-50 \%$ and returned to the levels recorded before c. AD 1200 (Figure 4). This event may be correlated to the Black Death pandemic that first struck Sweden in AD 1350 
and returned throughout the 14 th and 15 th centuries, although the local effect is not known in detail (Lagerås, 2007, 2013; Lagerås et al., 2016; Myrdal, 2012). Myrdal (2012) estimated that 60-70\% of all farms in the uplands were abandoned.

The total LOVE-based evenness and tree evenness were lower during $\AA 3 \mathrm{~b}$, which reflects the increased dominance of Picea. Despite relatively low openness during $\AA 3 \mathrm{~b}$, evenness for herbs increased, which suggests the herb taxa present during this period covered more equal proportions of the landscape. The relationship between openness and estimates of floristic diversity indicates that many species can survive during periods of succession from open land to woodland. It is also possible that there was a shift from species favoured by open areas to species favoured by mixed woodland with Picea and Fagus.

At Lindhultsgöl, there is no clear indication of land-use abandonment after the Black Death, possibly because the extent of grasslands and cultivated fields was generally lower before the pandemic around this lake. However, the minor decrease in CHAR at c. AD 1400 may indicate a temporary abandonment also at Lindhultsgöl (Figure 5).

\section{Re-expansion during the early modern period}

From c. AD 1600 ( $\AA 4)$, the increased cover of cereals, Poaceae and Juniperus together with the decreased tree cover at Åbodasjön indicates agricultural expansion (Figure 4). Picea and Fagus, which had expanded after c. AD 1400, now declined again, which suggests that the areas previously used for agriculture were reclaimed. Juniperus and Empetrum, which are associated with dry pastures, increased during this period (Appendix 2). Also Corylus, which is light-demanding, increased from c. AD 1700, suggesting that semi-open pastures were common. CHAR increased during the second half of $\AA 4$, which suggests that fires became more common in the area, probably as a result of land clearance. This inferred intensification of agricultural activity is in agreement with historical and palaeoecological records, suggesting an expansion phase during the 16th century in the upland areas of southern Sweden (Lagerås, 2007; Larsson, 1972). Farms situated around the study lakes are mentioned in preserved historical documents from AD 1545 (Larsson, 1980).

At Lindhultsgöl, Juniperus and cereals increased around AD 1400 (L2b), which indicates more widespread agricultural activity (Figure 5). Sinapis type, which represents species associated with fresh meadows and pastures, appeared in the pollen record at c. AD 1500 and is recorded until the present (Appendix 2).

A pronounced increase in openness at Lindhultsgöl occurred at c. AD 1700. The L3 period (c. AD 1700-1900) is characterised by higher cover of Poaceae, Calluna vulgaris and other herbs, and lower cover of cereals, which indicates that pastures expanded at the expense of arable land (Figure 5). At the same time, Juniperus decreased and CHAR increased, a relationship that is only clear during the L3 period, which suggests a different land management during this time at Lindhultsgöl. Juniperus is fire-sensitive and grazing areas may have been improved by the use of fire. Pastures can be maintained by regular burning to rejuvenate the heathland communities and to remove shrubs. This expansion in pastures coincides with a pronounced increase in palynological richness, which suggests that fire also played an important role in achieving high floristic diversity. In general, fire activity inferred from charcoal in southern Sweden shows a variable but increasing trend during the last 3000-4000 years (Lindbladh et al., 2003; Olsson et al., 2010). A large proportion of these fires is attributed to human-induced burning for forest clearance, temporary crop cultivation and improvement of the quality of grasslands (Cui et al., 2013; Olsson et al., 2010). The source area of the microscopic charcoal may be much larger than the predicted RSAP used in this study, that is, up to $20-100 \mathrm{~km}$ (Conedera et al., 2009).
The population in Slätthög Parish increased gradually and reached a maximum during the end of the 19th century, which represents a fourfold increase since c. AD 1700 (Andersson Palm, 2000; Figures 4 and 5). Despite this population increase, changes in agricultural land-use, as reflected by openness, were relatively limited between c. AD 1600 and 1900 at Åbodasjön and between c. AD 1700 and 2000 at Lindhultsgöl. This implies that a largely constant cover of agricultural land could feed more people, especially during the 19th century, probably as a result of more efficient nutrient supply to the arable land and other improvements of agricultural practices, including land divisions, more effective manuring, crop rotation, irrigation and marling (Emanuelsson, 2009; Myrdal and Morell, 2011).

\section{Modern land-use}

In general, small-scale agriculture gave way to modern land-use with a focus on commercial forestry and crop cultivation during the last c. 100 years, which led to a marked reduction in the rural population (Myrdal and Morell, 2011). At Åbodasjön, this transition is reflected by increased Picea cover and decreased cover of cereals, Juniperus and other herbs ( $\AA 5)$, whereas increased cover of Picea and cereals and decreased cover of Betula and Calluna vulgaris are recorded at Lindhultsgöl (L4). These changes suggest that woodlands expanded in areas previously used for grazing, and to some extent in areas used for crop cultivation at Åbodasjön. In addition, several herbs related to meadows, pastures and forest declined at Åbodasjön (Appendix 2). According to historical data, this landscape transformation became possible through the introduction of artificial fertilisers, which led to a manifold increase in food production. Thereby, it became unnecessary to keep animals for nutrient supply to the fields, and with the introduction of grass cultivation, this change led to a general reduction of meadows and pastures, which are generally associated with high floristic diversity (Cousins, 2011). However, the reduction of meadows and pastures during the 20th century is difficult to trace in the pollen record (e.g. openness remained largely unchanged and Poaceae increased slightly at Lindhultsgöl), probably because grass cultivation in the fields compensated for the reduction of permanent grasslands, at least during the first half of the 20th century. During the second half of the century, aerial photographs show that both cultivated fields and grasslands declined, while clear-cuts where grass may grow expanded dramatically (Mazier et al., 2015). A decrease in palynological richness related to this transition was only recorded at Åbodasjön. There was probably enough open land and woodland in different stages of succession for the floristic richness to remain at a generally high level, at least at Lindhultsgöl. At Åbodasjön, LOVE-based herb evenness decreased during the modern land-use period, which reflects a decline of many herb taxa. At the same time, Poaceae cover remains unchanged, probably because of increased grass cultivation and clear-cuts. CHAR decreased during the 20th century, which may be explained by less human-induced burning or more efficient fire suppression. The decreased fire activity during the modern land-use period is consistent with comparable declines all over Sweden from the 18th to 19th centuries and onwards (Lindbladh et al., 2003; Niklasson and Drakenberg, 2001).

\section{Regional perspective and implications for ecosystem management}

The LRA approach used in this study allowed us to quantify the degree of vegetation changes through time. The two study sites show several differences in land-use history that would not be possible to infer from pollen data alone. Mazier et al. (2015) tested the LRA performance, using the same pollen data as in this study covering the last 200 years, by comparing the LRA output with historical records. The comparison showed that the LRA 
estimates were in general agreement with historical maps and aerial photographs over the last 200 years, however, tended to overestimate grassland cover by $10-30 \%$ compared with historical maps from the 19th century (Mazier et al., 2015). These studies show that the LRA is a useful tool in combination with historical records and traditional pollen data.

Fredh et al. $(2012,2013)$ analysed the relationship between land-use and floristic diversity in the province of Småland at the regional scale. Agricultural land-use was most widespread at $\mathrm{c}$. AD 350-1850, which correlates broadly with high values of palynological richness (Fredh et al., 2013). REVEALS-based evenness was highest at c. AD 500-1600 and showed much lower values during the last century compared with the previous c. 2600 years, which indicates that the present-day vegetation distribution is unusual in a millennial perspective (Fredh et al., 2013). Similarly, the present study at the local scale shows generally higher values of palynological richness during periods of more widespread agriculture, c. AD 1200-1900 at Åbodasjön and c. AD 1700-2000 at Lindhultsgöl. LOVE-based evenness for herbs shows the lowest values in the modern land-use period at Åbodasjön, which suggests a relatively unusual vegetation composition during the modern land-use period.

Today the major part of the uplands of southern Sweden is mainly used for timber production and to less extent cereal cultivation (Antonsson and Jansson, 2011). Relatively few species dominate large areas and there is a distinct division between landuse types, which has led to a decline in areas with high floristic diversity, such as meadows and pastures (Cousins, 2011; Cui et al., 2014). With the purpose of mitigating the on-going loss of species, we may learn from historical landscapes and use past rates and degrees of vegetation change inferred from pollen records to identify more sustainable land-use strategies (Berglund et al., 2008; Cui et al., 2013).

In this study, the 13th-19th centuries represent a historical period of land-use with relatively high floristic diversity. Compared with modern land-use, this traditional agriculture was probably characterised by more gradual changes in intensity, from the cultivated fields close to the settlements towards meadows and common land in more peripheral areas, and fires were more frequent. This type of landscape therefore allowed more species to coexist (Emanuelsson, 2009; Montoya et al., 2012). As suggested by retained relatively high levels of palynological richness also during temporary phases of regression, this traditional agricultural landscape made it possible for many plants to survive through periods of succession and reforestation. Landscape elements typical for traditional agriculture and characterised by high floristic diversity, such as meadows and pastures, decreased in importance within our study area of southern Sweden during the last c. 100 years, while tree cover and areas used for crop cultivation increased. This increase in tree cover was largely an effect of the expansion of land area used for timber production and associated with a replacement of deciduous woodland and open land with less diverse coniferous forest.

Ecosystem management of selected areas within the landscape of modern land-use is an important strategy to mitigate the ongoing loss of floristic diversity in southern Sweden and elsewhere (Harrison et al., 2010; Haslett et al., 2010). The results from this study suggest that the landscape elements in these selected areas should be diverse and include a significant part of open land. The land-use should vary from intensely managed meadows and pastures to areas in fallow and woodland regrowth. The landscape elements should be in different stages of succession and fire should be used to manage some of the grasslands.

\section{Acknowledgements}

We are grateful for Urban Emanuelsson's inspiration and encouragement to work on this topic, and the members of the LANDCLIM project and the NordForsk network (co-ordinated by
Marie-José Gaillard) are acknowledged for discussions and collaboration. We thank Shinya Sugita for providing the REVEALS and LOVE programs and theoretical support.

\section{Funding}

This work was funded by the Swedish Research Council Formas through grants 2007-1012 (Revealing the dynamics of discontinuous management and biodiversity at different spatial and temporal scales in the traditional cultural landscape), 2006-547 (Brownification of streams, lakes, and coastal waters - an effect of climate change or land-use?), the Swedish Research Council, Helge Ax:son Johnson Foundation, The Royal Physiographic Society in Lund, The Royal Swedish Academy of Sciences and The Swedish Foundation for International Cooperation in Research and Higher Education. FM was supported by funding made available by the French ANR 2010 JCJC 1804 01, MODE RESPYR.

\section{References}

Alexandersson H, Karlström C and Larsson-McCan S (1991) Temperaturen och nederbörden i Sverige 1960-1990. Norrköping: Swedish Meteorological and Hydrological Institute.

Andersson Palm L (2000) Folkmängden i Sveriges socknar och kommuner 1571-1997. Göteborg: Books-on-Demand.

Anton C, Young J, Harrison PA et al. (2010) Research needs for incorporating the ecosystem service approach into EU biodiversity conservation policy. Biodiversity and Conservation 19: 2979-2994.

Antonsson H and Jansson U (2011) Agriculture and Forestry in Sweden since 1900. Stockholm: The Royal Swedish Academy of Agriculture and Forestry.

Appleby PG (2001) Chronostratigraphic techniques in recent sediments. In: Last WM and Smol JP (eds) Tracking Environmental Change Using Lake Sediments. Dordrecht: Springer, pp. 171-203.

Barnosky AD, Matzke N, Tomiya S et al. (2011) Has the Earth's sixth mass extinction already arrived? Nature 471: 51-57.

Berglund BE and Ralska-Jasiewiczowa M (1986) Pollen analysis and pollen diagrams. In: Berglund BE (ed.) Handbook of Holocene Palaeoecology and Palaeohydrology. Chichester: John Wiley \& Sons, pp. 455-484.

Berglund BE, Gaillard M-J, Björkman L et al. (2008) Long-term changes in floristic diversity in southern Sweden: Palynological richness, vegetation dynamics and land-use. Vegetation History and Archaeobotany 17: 573-583.

Berglund BE, Lagerås P and Regnell J (2002) Odlingslandskapets historia i Sydsverige - en pollenanalytisk syntes. In: Berglund BE and Börjesson K (eds) Markens minnen. Stockholm: Swedish National Heritage Board, pp. 150-169.

Beug H-J (1961) Leitfaden der Pollenbestimmung. Lieferung 1. Stuttgart: S. Fischer Verlag.

Beug H-J (2004) Leitfaden der Pollenbestimmung für Mitteleuropa und angrenzende Gebiete. München: Pfeil.

Birks HJB and Line JM (1992) The use of rarefaction analysis for estimating palynological richness from quaternary pollenanalytical data. The Holocene 2: 1-10.

Birks HJB, Felde VA, Bjune AE et al. (2016) Does pollen-assemblage richness reflect floristic richness? A review of recent developments and future challenges. Review of Palaeobotany and Palynology 228: 1-25.

Boyle J (2000) Rapid elemental analysis of sediment samples by isotope source XRF. Journal of Paleolimnology 23: 213-221.

Bragée P, Choudhary P, Routh J et al. (2013) Lake ecosystem responses to catchment disturbance and airborne pollution: An 800-year perspective in southern Sweden. Journal of Paleolimnology 50: 545-560.

Brännvall ML, Bindler R, Emteryd O et al. (2001) Four thousand years of atmospheric lead pollution in northern Europe: 
A summary from Swedish lake sediments. Journal of Paleolimnology 25: 421-435.

Bronk Ramsey C (2008) Deposition models for chronological records. Quaternary Science Reviews 27: 42-60.

Bronk Ramsey C (2009) Bayesian analysis of radiocarbon dates. Radiocarbon 51: 337-360.

Broström A, Gaillard M-J, Ihse M et al. (1998) Pollen-landscape relationship in modern analogues of ancient cultural landscapes in southern Sweden - A first step towards quantification of vegetation openness in the past. Vegetation History and Archaeobotany 7: 189-201.

Broström A, Nielsen AB, Gaillard M-J et al. (2008) Pollen productivity estimates of key European plant taxa for quantitative reconstruction of past vegetation: A review. Vegetation History and Archaeobotany 17: 461-478.

Broström A, Sugita S and Gaillard M-J (2004) Pollen productivity estimates for the reconstruction of past vegetation cover in the cultural landscape of southern Sweden. The Holocene 14: 368-381.

Broström A, Sugita S, Gaillard M-J et al. (2005) Estimating the spatial scale of pollen dispersal in the cultural landscape of southern Sweden. The Holocene 15: 252-262.

Bunting MJ, Gaillard M-J, Sugita S et al. (2004) Vegetation structure and pollen source area. The Holocene 14: 651-660.

Conedera M, Tinner W, Neff C et al. (2009) Reconstructing past fire regimes: Methods, applications, and relevance to fire management and conservation. Quaternary Science Reviews 28: 435-456.

Cousins SAO (2011) Semi-natural grasslands: From grazing resource to an environmental issue. In: Antonsson $\mathrm{H}$ and Jansson U (eds) Agriculture and Forestry in Sweden since 1900. Stockholm: The Royal Swedish Academy of Agriculture and Forestry, pp. 324-337.

Cousins SAO, Ohlson H and Eriksson O (2007) Effects of historical and present fragmentation on plant species diversity in semi-natural grasslands in Swedish rural landscapes. Landscape Ecology 22: 723-730.

Cui Q-Y, Gaillard M-J, Lemdahl G et al. (2013) The role of tree composition in Holocene fire history of the hemiboreal and southern boreal zones of southern Sweden, as revealed by the application of the landscape reconstruction algorithm: Implications for biodiversity and climate-change issues. The Holocene 23: 1747-1763.

Cui Q-Y, Gaillard M-J, Lemdahl G et al. (2014) Historical landuse and landscape change in southern Sweden and implications for present and future biodiversity. Ecology and Evolution 4: 3555-3570.

Dahlström A (2008) Grazing dynamics at different spatial and temporal scales: Examples from the Swedish historical record A.D. 1620-1850. Vegetation History and Archaeobotany 17: $563-572$.

Davis MB (2000) Palynology after Y2K - Understanding the source area of pollen in sediments. Annual Review of Earth and Planetary Sciences 28: 1-18.

Dawson TP, Jackson ST, House JI et al. (2011) Beyond predictions: Biodiversity conservation in a changing climate. Science 332: 53-58.

Eisenhut G (1961) Untersuchungen über die Morphologie und Ökologie der Pollenkörner heimischer und fremdländischer Waldbäume. Hamburg: Paul Parey.

Emanuelsson U (2009) The Rural Landscapes of Europe - How Man Has Shaped European Nature. Stockholm: Forma Publishing.

Fredén C (1994) Geology. Stockholm: National Atlas of Sweden.

Fredh D, Broström A, Rundgren M et al. (2013) The impact of land-use change on floristic diversity at regional scale in southern Sweden 600 BC-AD 2008. Biogeosciences 10: 3159-3173.

Fredh D, Broström A, Zillén L et al. (2012) Floristic diversity in the transition from traditional to modern land-use in southern Sweden A.D. 1800-2008. Vegetation History and Archaeobotany 21: 439-452.

Grimm E (1992) TILIA and TILIA GRAPH: Pollen spreadsheet and graphics program. In: 8th International Palynological Congress. Program and Abstracts. Aix-en-Provence, France, 56.

Harrison PA, Vandewalle M, Sykes MT et al. (2010) Identifying and prioritising services in European terrestrial and freshwater ecosystems. Biodiversity and Conservation 19: 2791-2821.

Haslett JR, Berry PM, Bela G et al. (2010) Changing conservation strategies in Europe: A framework integrating ecosystem services and dynamics. Biodiversity and Conservation 19: 2963-2977.

Hellman S, Bunting J and Gaillard M-J (2009) Relevant source area of pollen in patchy cultural landscapes and signals of anthropogenic landscape disturbance in the pollen record: A simulation approach. Review of Palaeobotany and Palynology 153: 245-258.

Hellman S, Gaillard M-J, Broström A et al. (2008) Effects of the sampling design and selection of parameter values on pollen-based quantitative reconstructions of regional vegetation: A case study in southern Sweden using the REVEALS model. Vegetation History and Archaeobotany 17: 445-459.

Jackson ST and Hobbs RJ (2009) Ecological restoration in the light of ecological history. Science 325: 567-569.

Jowsey PC (1966) An improved peat sampler. New Phytologist 65: $245-248$.

Lagerås P (2007) The Ecology of Expansion and Abandonment: Medieval and Post-Medieval Land-Use and Settlement Dynamics in a Landscape Perspective. Stockholm: Swedish National Heritage Board.

Lagerås P (2013) Medieval colonization and abandonment in the South-Swedish Uplands: A review of settlement and land-use dynamics inferred from pollen data. Archaeologica Baltica 20: 77-90.

Lagerås P, Broström A, Fredh D et al. (2016) Abandonment, agricultural change and ecology. In: Lagerås $\mathrm{P}$ (ed.) Environment, Society and the Black Death - An Interdisciplinary Approach to the Late-Medieval Crisis. Oxford: Oxbow Books, pp. 30-68.

Larsson L-O (1972) Kolonisation och befolkningsutveckling $i$ det Svenska agrarsamhället 1500-1640. Lund: Bibliotheca Historica Lundensis, p. 27.

Larsson L-O (1980) Småländsk bebyggelsehistoria. 1. Från vikingatid till Vasatid. 1:2 Allbo härad. Växjö: Acta Wexionensia.

Levin I and Kromer B (2004) The tropospheric ${ }^{14} \mathrm{CO}_{2}$ level in mid-latitudes of the Northern Hemisphere (1959-2003). Radiocarbon 46: 1261-1272.

Levin I, Hammer S, Kromer B et al. (2008) Radiocarbon observations in atmospheric $\mathrm{CO}_{2}$ : Determining fossil fuel $\mathrm{CO}_{2}$ over Europe using Jungfraujoch observations as background. Science of the Total Environment 391: 211-216.

Lindbladh M (1999) The influence of former land-use on vegetation and biodiversity in the boreo-nemoral zone of Sweden. Ecography 22: 485-498.

Lindbladh M, Niklasson M and Nilsson SG (2003) Long-time record of fire and open canopy in a high biodiversity forest in southeast Sweden. Biological Conservation 114: 231-243.

MacDonald GM, Bennett KD, Jackson ST et al. (2008) Impacts of climate change on species, populations and communities: 
Palaeobiogeographical insights and frontiers. Progress in Physical Geography 32: 139-172.

Magurran AE (2004) Measuring Biological Diversity. Oxford: Wiley-Blackwell.

Mazier F, Broström A, Bragée P et al. (2015) Two hundred years of land-use change in the South Swedish Uplands: Comparison of historical map-based estimates with pollen-based reconstruction using the Landscape Reconstruction Algorithm. Vegetation History and Archaeobotany 24: 555-570.

Mazier F, Gaillard M-J, Kuneš P et al. (2012) Testing the effect of site selection and parameter setting on REVEALS-model estimates of plant abundance using the Czech Quaternary Palynological Database. Review of Palaeobotany and Palynology 187: 38-49.

Meltsov V, Poska A, Odgaard BV et al. (2011) Palynological richness and pollen sample evenness in relation to floristic diversity in southern Estonia. Review of Palaeobotany and Palynology 166: 344-351.

Meltsov V, Poska A, Reitalu T et al. (2012) The role of landscape structure in determining palynological and floristic richness. Vegetation History and Archaeobotany 22: 39-49.

Montoya D, Rogers L and Memmott J (2012) Emerging perspectives in the restoration of biodiversity-based ecosystem services. Trends in Ecology \& Evolution 27(12): 666-672.

Moore PD, Webb JA and Collinson ME (1991) Pollen Analysis. 2nd edition. Oxford: Wiley-Blackwell.

Myrdal J (2012) Scandinavia. In: Kitsikopoulos H (ed.) Agrarian Change and Crisis in Europe, 1200-1500. New York: Routledge, pp. 204-249.

Myrdal J and Morell M (2011) The Agrarian History of Sweden, from $4000 B C$ to $A D$ 2000. Nordic Lund: Academic Press.

Nielsen AB (2004) Modelling pollen sedimentation in Danish lakes at c. A.D. (1800) An attempt to validate the POLLSCAPE model. Journal of Biogeography 31: 1693-1709.

Niklasson M and Drakenberg B (2001) A 600-year tree-ring fire history from Norra Kvills National Park, southern Sweden: Implications for conservation strategies in the hemiboreal zone. Biological Conservation 101: 63-71.

Odgaard BV (2007) Reconstructing past biodiversity development. In: Elias SA (ed.) Encyclopedia of Quaternary Science. Amsterdam: Elsevier, pp. 2508-2514.

Olsson F, Gaillard M-J, Lemdahl G et al. (2010) A continuous record of fire covering the last 10,500 calendar years from southern Sweden - The role of climate and human activities. Palaeogeography, Palaeoclimatology, Palaeoecology 291: $128-141$.

Pielou EC (1966) The measurement of diversity in different types of biological collections. Journal of Theoretical Biology 13: 131-144.

Poschlod P, Bakker JP and Kahmen S (2005) Changing land use and its impact on biodiversity. Basic and Applied Ecology 6: 93-98.

Prentice IC (1985) Pollen representation, source area, and basin size: Toward a unified theory of pollen analysis. Quaternary Research 23: 76-86.

Prentice IC (1988) Records of vegetation in time and space: The principles of pollen analysis. In: Huntley B and Webb T (eds)
Vegetation History. Dordrecht: Kluwer Academic Publishers, pp. 17-42.

Punt W (2003 [1976]) The Northwest European Pollen Flora I-VIII. Amsterdam: Elsevier.

Redman CL (1999) Human Impact on Ancient Environments. Tucson, AZ: University of Arizona Press.

Reimer PJ, Baillie MGL, Bard E et al. (2009) IntCal09 and Marine09 radiocarbon age calibration curves, $0-50,000$ years cal BP. Radiocarbon 51: 1111-1150.

Renberg I and Hansson H (2008) The HTH sediment corer. Journal of Paleolimnology 40: 655-659.

Renberg I, Bindler R and Brännvall ML (2001) Using the historical atmospheric lead-deposition record as a chronological marker in sediment deposits in Europe. The Holocene 11: 511-516.

Sjörs H (1963) Amphi-atlantic zonation, nemoral to arctic. In: Löve A and Löve D (eds) North Atlantic Biota and Their History. Oxford: Pergamon Press, pp. 109-125.

Stockmarr J (1971) Tablets with spores used in absolute pollen analysis. Pollen et Spores 13: 615-621.

Stuart A and Ord JK (1994) Kendall's Advanced Theory of Statistics, Distribution Theory (vol. 1). London: Edward Arnold.

Sugita S (1993) A model of pollen source area for an entire lake surface. Quaternary Research 39: 239-244.

Sugita S (1994) Pollen representation of vegetation in quaternary sediments: Theory and method in patchy vegetation. Journal of Ecology 82: 881-897.

Sugita S (2007a) Theory of quantitative reconstruction of vegetation I: Pollen from large sites REVEALS regional vegetation composition. The Holocene 17: 229-241.

Sugita S (2007b) Theory of quantitative reconstruction of vegetation II: All you need is LOVE. The Holocene 17: 243-257.

Sugita S, Gaillard M-J and Broström A (1999) Landscape openness and pollen records: A simulation approach. The Holocene 9: 409-421.

Sugita S, Parshall T, Calcote R et al. (2010) Testing the landscape reconstruction algorithm for spatially explicit reconstruction of vegetation in northern Michigan and Wisconsin. Quaternary Research 74: 289-300.

Thompson R, Bloemendal J, Dearing JA et al. (1980) Environmental applications of magnetic measurements. Science 207: 481-486.

Van der Knaap WO (2009) Estimating pollen diversity from pollen accumulation rates: A method to assess taxonomic richness in the landscape. The Holocene 19: 159-163.

Van Dyke F (2008) Conservation Biology: Foundations, Concepts, Applications, 2nd edition. Dordrecht: Springer.

Willis KJ and Bhagwat SA (2010) Questions of importance to the conservation of biological diversity: Answers from the past. Climate of the Past 6: 759-769.

Willis KJ, Bailey RM, Bhagwat SA et al. (2010) Biodiversity baselines, thresholds and resilience: Testing predictions and assumptions using palaeoecological data. Trends in Ecology \& Evolution 25: 583-591. 


\section{Appendix I}

Methods to establish chronologies for Fiolen, Åbodasjön and Lindhultsgöl (first presented in Bragée et al., 2013; Fredh et al., 2013)

Fieldwork and core correlation. For all three lakes, overlapping sediment successions were retrieved using Russian and gravity corers during fieldwork in 2008 (Jowsey, 1966; Renberg and Hansson, 2008). For Fiolen, an additional core was retrieved using a piston corer. For further analysis, the surface sediments (spanning $32 \mathrm{~cm}$ at Åbodasjön, $30 \mathrm{~cm}$ at Lindhultsgöl and $45 \mathrm{~cm}$ at Fiolen) were used together with the uppermost c. 1-1.4 m sediment sequence retrieved with a Russian corer (from Åbodasjön and Lindhultsgöl) or a piston corer (from Fiolen). For Fiolen, a few radiocarbon datings were also performed on parallel Russian cores (Table 2; Figure 6). For all lakes, correlations between the cores were obtained using mineral magnetic properties (Thompson et al., 1980) and element compositions measured with x-ray fluorescence (Boyle, 2000).

Gamma spectroscopy. A total of 26 samples from Fiolen, 25 samples from Åbodasjön and 20 samples from Lindhultsgöl were analysed for the activity of ${ }^{210} \mathrm{~Pb},{ }^{137} \mathrm{Cs}$ and ${ }^{226} \mathrm{Ra}$, using a Canberra lowbackground Germanium well-detector at the Gamma Dating Centre, University of Copenhagen. The fraction of total ${ }^{210} \mathrm{~Pb}$ that is deposited on the lake surface from the atmosphere (i.e. the unsupported ${ }^{210} \mathrm{~Pb}$ ) was calculated based on the ${ }^{226} \mathrm{Ra}$ data obtained. The constant rate of supply (CRS) model (Appleby, 2001) was applied to the profiles using a modified method in which the activity of the lowermost sample was calculated on the basis of a regression of unsupported ${ }^{210} \mathrm{~Pb}\left(\mathrm{~Bq} \mathrm{~kg}^{-1}\right)$ versus accumulated dry density $\left(\mathrm{g} \mathrm{cm}^{-2}\right)$.

For Fiolen, because of the irregular profile of ${ }^{210} \mathrm{~Pb}$ below $15 \mathrm{~cm}$, only the nine samples above $15 \mathrm{~cm}$ that show decreasing trends in ${ }^{210} \mathrm{~Pb}$ activity with depth were included in the CRS model (Appleby, 2001). However, using only the lead dates from above $15 \mathrm{~cm}$ we had to assume that some of the measured elements are mobile in the sediment below this depth, which is supported by the high activity of ${ }^{137} \mathrm{Cs}$ at depths below $14 \mathrm{~cm}$ that correspond to ages older than $\mathrm{c}$. AD 1950 according to the CRS model (Figure 6). ${ }^{137} \mathrm{Cs}$ is normally only found in sediments younger than AD 1950 (Appleby, 2001). In an earlier study focussing on the last 200 years, Fredh et al. (2012) included 20 samples in the CRS model and therefore yielded younger ages in that interval compared with the present study.

For Åbodasjön and Lindhultsgöl, both records show decreasing trends in ${ }^{210} \mathrm{~Pb}$ activity with depth, with the exception of the uppermost 1-cm interval in Åbodasjön, which displays lower activity (Figure 7). Data from the latter section were interpreted with caution as the low top activity may indicate sediment mixing. A peak in ${ }^{137} \mathrm{Cs}$ detected at $9.5 \mathrm{~cm}$ depth in Åbodasjön was dated to 19811985 based on ${ }^{210} \mathrm{~Pb}$, likely reflecting the Chernobyl fall-out event in 1986. The Lindhultsgöl record shows peaks in ${ }^{137} \mathrm{Cs}$ in the uppermost sample and at about $6 \mathrm{~cm}$ depth, the latter dated to 1962-1972 based on ${ }^{210} \mathrm{~Pb}$, and thus probably reflecting the culmination of nuclear weapons testing in 1963 . The presence of ${ }^{137} \mathrm{Cs}$ in strata deposited in the early 1900 s according to the ${ }^{210} \mathrm{~Pb}$ records in both Åbodasjön and Lindhultsgöl (Figure 7) suggests some mobility of ${ }^{137} \mathrm{Cs}$ in these environments.

Radiocarbon. Using accelerator mass spectroscopy, 13 macroscopic plant remains and eight bulk gyttja samples were dated from Fiolen (Table 2). Three macroscopic plant remains and four bulk gyttja samples were dated from Åbodasjön and 2 macroscopic plant remains and three bulk gyttja samples were dated from Lindhultsgöl (Table 3). All dates were performed at the Radiocarbon Dating Laboratory, Lund University.

For Fiolen, most macroscopic plant remains were identified as terrestrial but a few were difficult to identify (Table 2). Only three of the macrofossil samples were larger than $2 \mathrm{mg}$ and pre-treated $(\mathrm{HCl}$ and $\mathrm{NaOH})$. This means that any potential contamination with modern material, for most of the samples, was not removed. For Åbodasjön and Lindhultsgöl, plant remains of terrestrial origin were identified. For all lakes, the OxCal program (v. 4.1; IntCa109) and the CaliBomb program (Levin's Vermunt and Schauinsland data sets) were used for calibration of ${ }^{14} \mathrm{C}$ dates based on calibration curves constructed from terrestrial and atmospheric samples (Bronk Ramsey, 2009; Levin and Kromer, 2004; Levin et al., 2008; Reimer et al., 2009).

For Fiolen, the dated macroscopic plant remains show rather scattered ages (Figure 6). Because of unexpectedly young ages for several macroscopic plant remains, due to suspected contamination, most of the small macrofossil samples were not included in the age model. The bulk dates show a rather well-defined slope with increased age at greater depth, indicating that the sediments have not been subject to major mixing or disturbance. The absolute ages for these bulk samples are, however, likely affected by a lake reservoir effect and therefore assumed to be too old (c. 200 to 400 year) and excluded from the age model.

For Åbodasjön and Lindhultsgöl, the dates obtained on terrestrial macroscopic plant remains fall along trajectories defined by extrapolated ${ }^{210} \mathrm{~Pb}$ data and lead pollution marker horizons. In contrast, all dates obtained on bulk sediments display substantially higher calibrated ages as compared with these trends, and were thus excluded from the age models. This is consistent with similar evidence of bulk sediment dates from other lakes in Sweden and elsewhere yielding anomalously high ages.

Pollution marker horizons. For all lakes, total lead concentrations at $1-11 \mathrm{~cm}$ intervals were determined using an S2 Ranger XRF spectrometer at the Department of Geography, University of Liverpool (Boyle, 2000). The spectrometer was calibrated using certified reference materials. Mass attenuation correction used theoretical alpha coefficients, the calculation taking the organic matter concentration into account. In addition, both total lead concentration and lead isotope ratios $(206 \mathrm{~Pb} / 207 \mathrm{~Pb})$ were measured at $4-6 \mathrm{~cm}$ intervals for Fiolen using Acid Dissolution (EPA 3052) and Quadrapole ICP-MS, at the Department of Geography, Durham University, UK.

Using the measurements above, the inferred historical pollution history can be used as a chronological framework by comparing with the known pattern of pollution lead through time (Brännvall et al., 2001; Renberg et al., 2001). The isotope ratios are used to separate local lead pollution from the regional lead pollution, the latter originating from central and southern Europe. Sulphide ores used in medieval times have a typical lead isotope ratio of about 1.17 and emissions from petrol a typical ratio of 1.15. Both of these are lower than the natural isotope ratio of bedrocks in Sweden.

For all lakes, a substantial increase in lead deposition occurs around $\mathrm{AD} 1000$, probably related to mining and metal production in Europe, reaching a peak at c. 1200. For Åbodasjön and Lindhultsgöl, a subsequent minimum around 1350 was recorded probably in response to plagues and recession and a peak around 1530 reflecting increased silver ore processing in continental Europe (Brännvall et al., 2001). These four marker horizons were all recorded in the Åbodasjön and Lindhultsgöl records and were used as input in the age models. In addition, a minor peak which likely represents the Roman cultural highstands around AD 0 yielded an additional chronological marker for Fiolen and Lindhultsgöl (Brännvall et al., 2001). The maximum lead concentration at c. 1975 was recorded in all lakes but was only used for Fiolen in subsequence age modelling. Due to uncertainties regarding the exact timing of the lead features, we used an approximation of \pm 50 -year uncertainty for all markers, except the modern maximum at $\mathrm{AD} 1975$ in the Fiolen record (uncertainty of \pm 5 years) and the AD 0 peak in the Lindhultsgöl record (uncertainty of \pm 150 years).

Age modelling. Age models were constructed using the $\mathrm{P}$ _Sequence deposition model in OxCal4.1, which takes the stratigraphic levels 


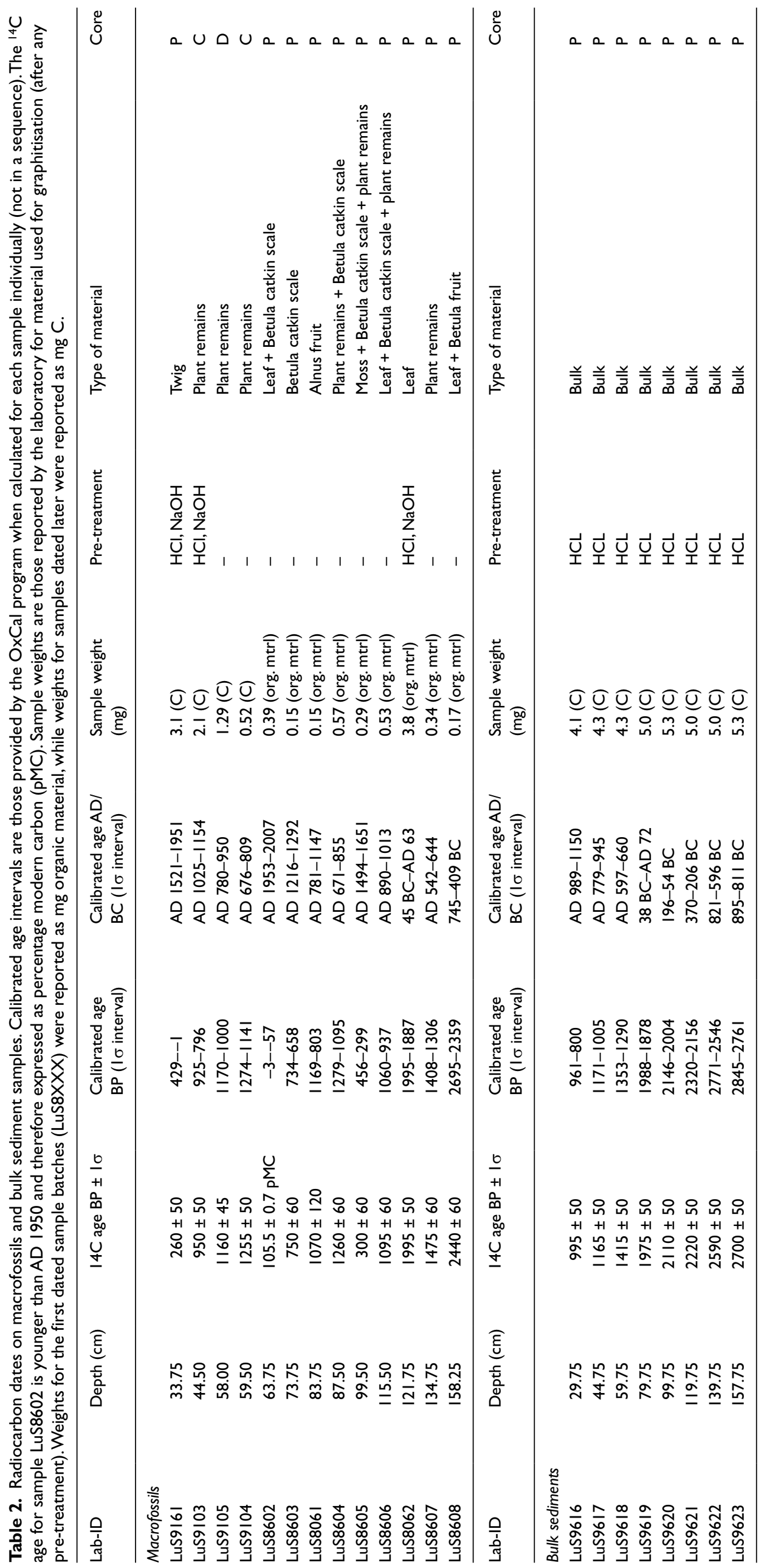



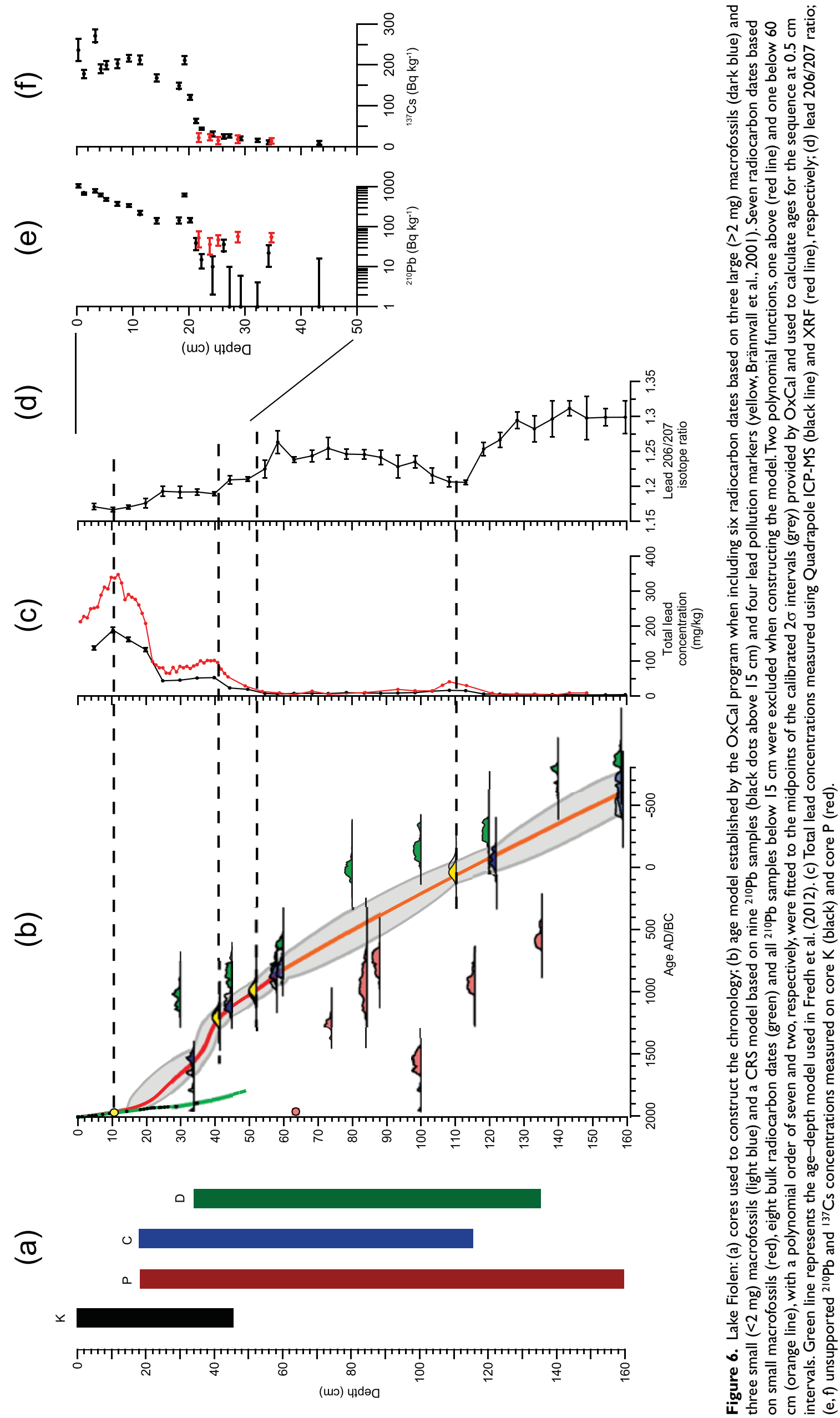

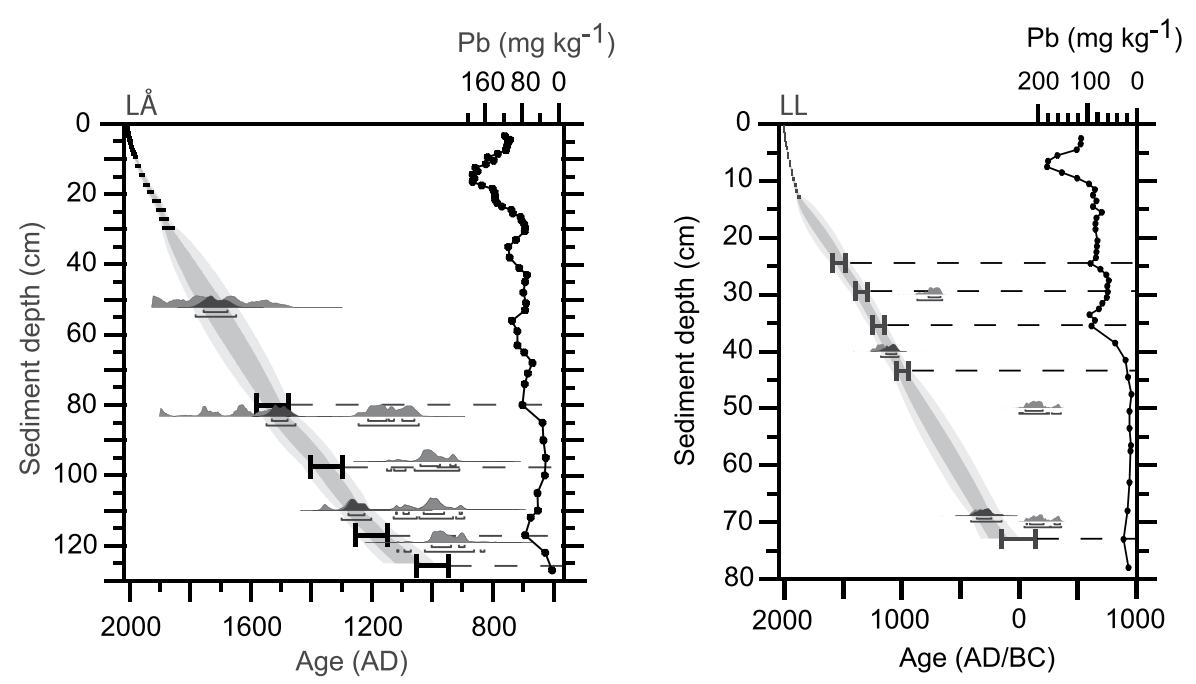

Figure 7. Lake Åbodasjön (LÅ) and Lake Lindhultsgöl (LL). Age-depth models based on ${ }^{210} \mathrm{~Pb}$ records (horizontal bars), calibrated radiocarbon dates obtained on terrestrial macrofossils, ${ }^{110} \mathrm{~Pb}$ dates and $\mathrm{Pb}$ pollution marker horizons (thick horizontal bars), along with the respective records of total $\mathrm{Pb}$ concentration. Depths of pollution marker horizons are marked by the dashed lines. The modelled $\pm I \sigma$ and $\pm 2 \sigma$ confidence intervals are marked by dark grey and grey shading, respectively.

Table 3. Accelerator mass spectrometry (AMS) ${ }^{14} \mathrm{C}$ dates from Åbodasjön and Lindhultsgöl.

\begin{tabular}{|c|c|c|c|c|c|}
\hline Sample depth $(\mathrm{cm})$ & Dated material & Weight (mg) & Lab. no. & ${ }^{14} \mathrm{C}$ age (BP) & $\begin{array}{l}\text { Calibrated age (mid } \\
\text { intercept) }( \pm 2 \sigma \text { ranges) }\end{array}$ \\
\hline \multicolumn{6}{|l|}{ Abodasjön } \\
\hline $52-52.5$ & Needle fragments (Picea) & 0.17 & LuS 7943 & $210 \pm 100$ & AD $1722 \pm 232$ \\
\hline $82.5-83$ & Bulk sample & $>20$ & LuS 8382 & $885 \pm 55$ & $A D|| 4 \mid \pm\|\|^{a}$ \\
\hline $82.5-83$ & Needle (Picea) & 0.61 & LuS 7942 & $250 \pm 60$ & $A D 1712 \pm 244$ \\
\hline $95.5-96$ & Bulk sample & $>20$ & LuS 8383 & $1045 \pm 50$ & $A D 1019 \pm 133^{a}$ \\
\hline $109.5-110$ & Bulk sample & $>20$ & LuS 8384 & $1020 \pm 50$ & $A D 1025 \pm 130^{a}$ \\
\hline $109.5-110$ & Unidentified bud scale & 0.45 & LuS 794I & $720 \pm 60$ & $A D 1292 \pm 106$ \\
\hline $118.5-119$ & Bulk sample & $>20$ & LuS 3885 & $1065 \pm 50$ & $A D 988 \pm 160^{a}$ \\
\hline \multicolumn{6}{|l|}{ Lindhultsgöl } \\
\hline $30-30.5$ & Bulk sample & $>20$ & LuS 8379 & $1280 \pm 50$ & $A D 763 \pm 107^{a}$ \\
\hline $40^{\mathrm{b}}$ & Unidentified bud scales, bud scale fragments & 0.61 & LuS 8924 & $885 \pm 60$ & $A D 1142 \pm 112$ \\
\hline $50-50.5$ & Bulk sample & $>20$ & LuS 8380 & $2120 \pm 50$ & $180 \pm 178 \mathrm{BC}^{\mathrm{a}}$ \\
\hline 70-70.5 & Bulk sample & $>20$ & LuS 838I & $2140 \pm 50$ & $203 \pm 157 \mathrm{BC}^{\mathrm{a}}$ \\
\hline $69 c$ & $\begin{array}{l}\text { Seed fragments (Betula), unidentified bud scale, bud } \\
\text { scale fragments, leaf fragments }\end{array}$ & 0.53 & LuS 8923 & $1725 \pm 60$ & $A D 28 I \pm 146$ \\
\hline 95-95.5 & Bud scale fragments, leaf fragments, bark (Pinus) & 3.8 & LuS 9088 & $3370 \pm 50$ & $1693 \pm 17 \mid \mathrm{BCa}$ \\
\hline $97-97.5$ & Bark (Pinus) & 3.4 & LuS 8828 & $3835 \pm 50$ & $2305 \pm 160 \mathrm{BC}^{\mathrm{a}}$ \\
\hline
\end{tabular}

aNot included in the age models.

bSampled sediment interval of $4 \mathrm{~cm}(40-44 \mathrm{~cm})$.

cSampled sediment interval of $10 \mathrm{~cm}(64-74 \mathrm{~cm})$.

of dated samples into account and allows for fluctuations in sedimentation rate (Bronk Ramsey, 2009). The degree of fluctuation allowed for by the program may be modified by varying the $k$-value (the number of accumulation events per unit depth). This parameter was chosen as high as possible and still resulted in an agreement index of $60 \%$ for the entire age model (Bronk Ramsey, 2008).

Because of inconsistencies between the chronological data obtained for Fiolen, it was difficult to establish a chronology for the sediment sequence. There were several options to construct an age model and the chronology is tentative. We chose to include all pre-treated macrofossils and as many small macrofossil samples and lead pollution marker horizons as possible. Our preferred agedepth model is based on six macrofossil samples (three pretreated), a CRS model (based on nine ${ }^{210} \mathrm{~Pb}$ samples) and four lead pollution markers (Figure 6). However, using this option we had to exclude most of the samples analysed for ${ }^{210} \mathrm{~Pb}$ activity used in the CRS model and most of the small macrofossil samples. Assuming this age model is correct, the maximum uncertainty $(2 \sigma)$ provided by $\mathrm{OxCal}$ is \pm 170 years.

For Åbodasjön, the preferred age model was based on radiocarbon dates obtained on three terrestrial macroscopic plant remains, a CRS model (based on $25{ }^{210} \mathrm{~Pb}$ samples) and four pollution marker horizons (Figure 7). Four dates obtained on bulk sediment were excluded from the age model. The maximum uncertainty $(2 \sigma)$ provided by $\mathrm{OxCal}$ is \pm c. 80 years.

For Lindhultsgöl, the preferred age model was based on two radiocarbon dates obtained on terrestrial macroscopic plant remains, a CRS model (based on $20^{210} \mathrm{~Pb}$ samples) and five pollution marker horizons (Figure 7). Three dates obtained on bulk sediment were excluded from the age model. The maximum uncertainty $(2 \sigma)$ provided by $\mathrm{OxCal}$ is \pm c. 100 years. For Lindhultsgöl, the macroscopic plant remains included in the age model were obtained from relatively extensive stratigraphic intervals $(4$ and $10 \mathrm{~cm}$ ), which adds some additional uncertainty to the chronology. 


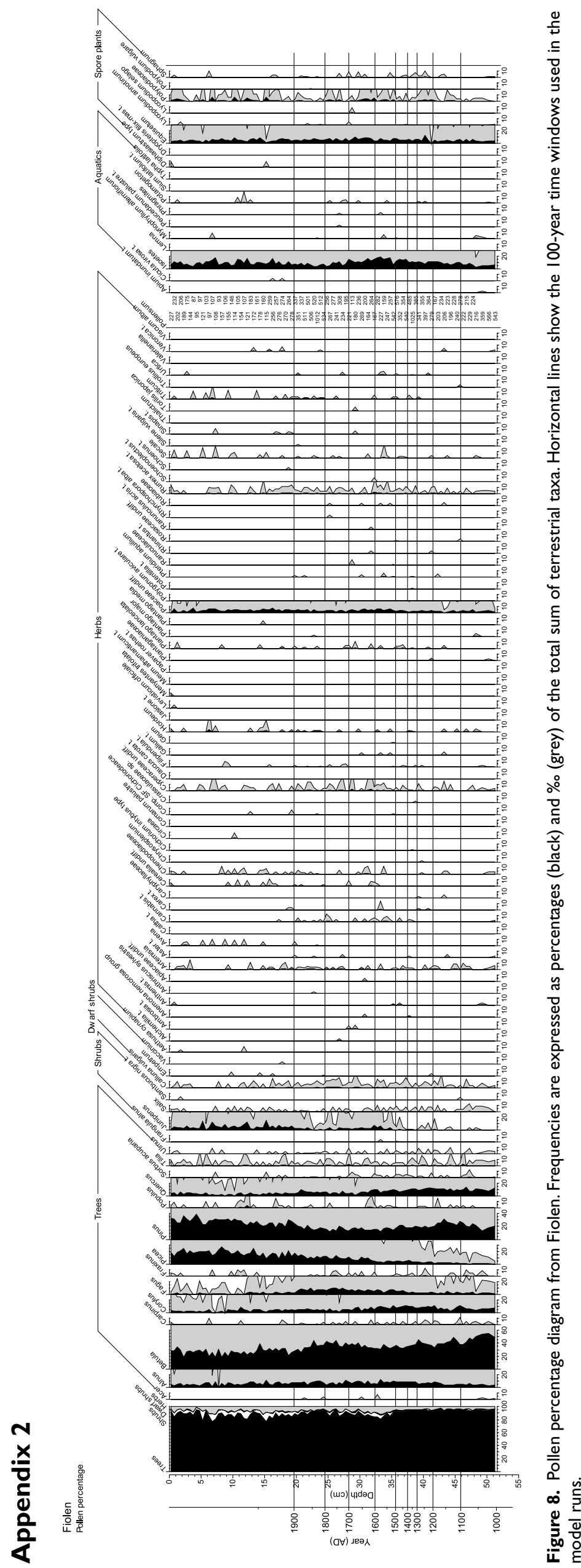



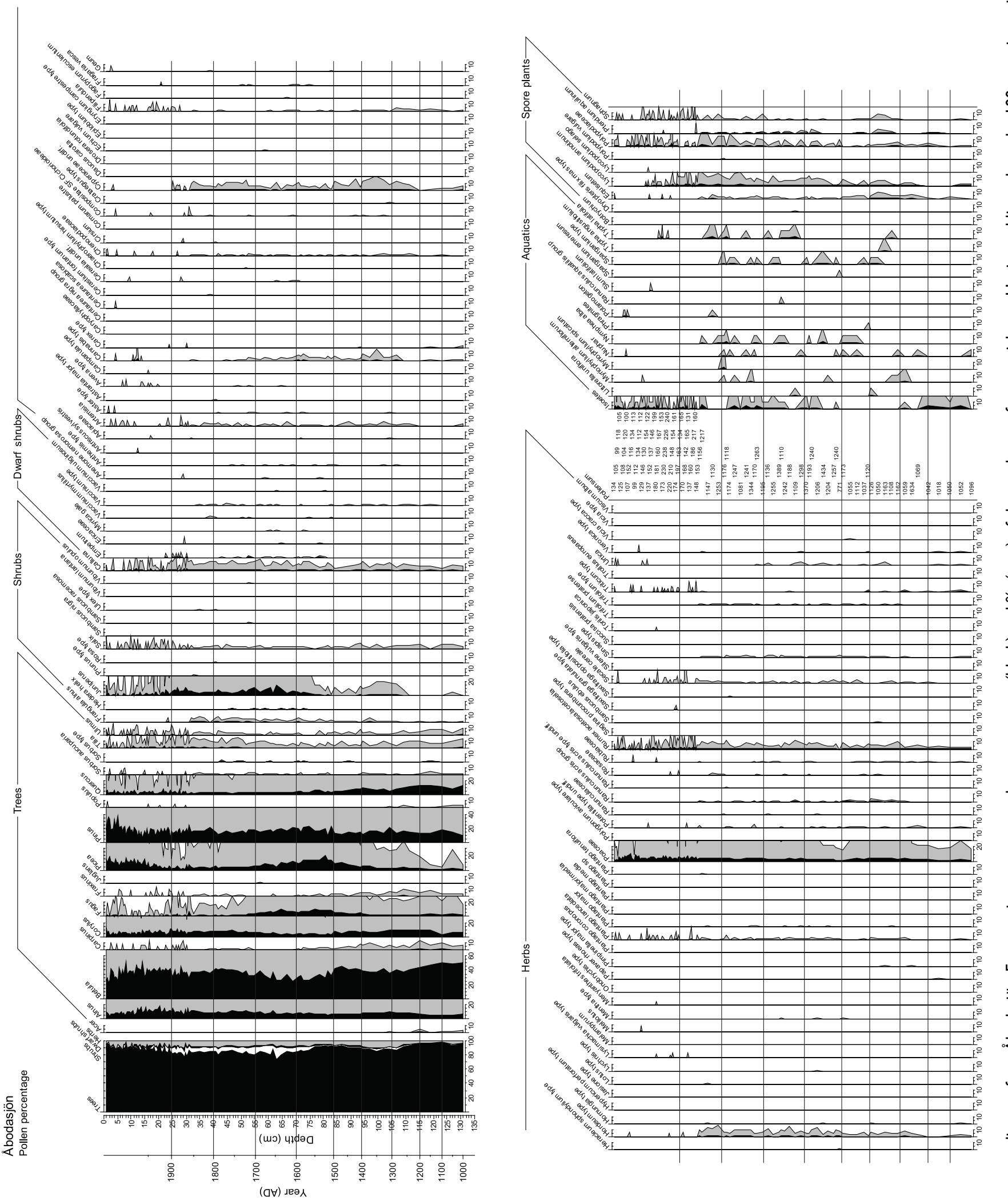

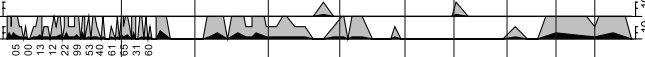

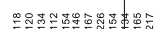

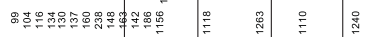

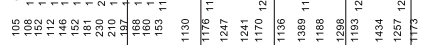

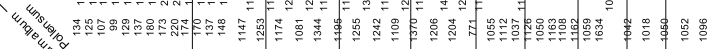

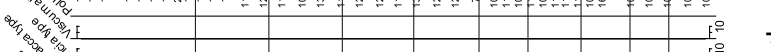

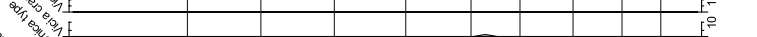

\%

sos

(1)

0

2\% \%

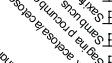

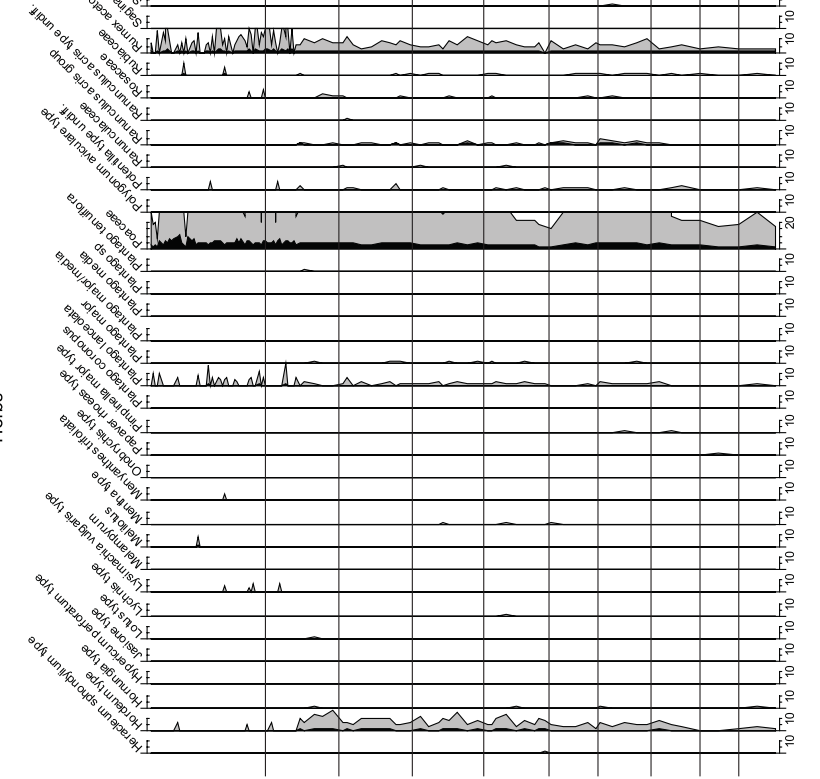




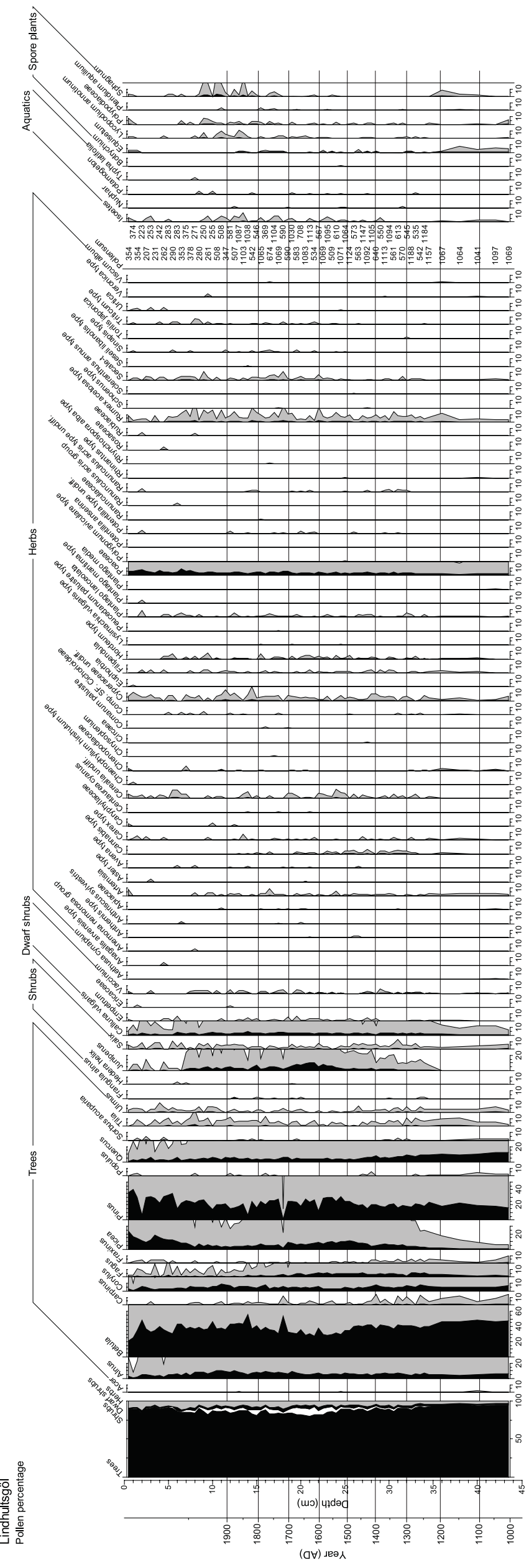

